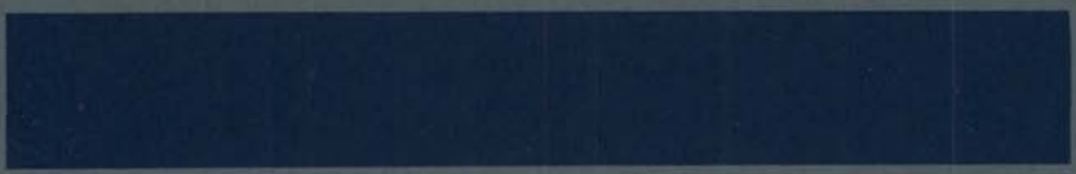

\title{
THERMAL CONDUCTIVITY AND ELECTRICAL RESISTIVITY OF URANIUM OXYCARBIDE
}

March 1969

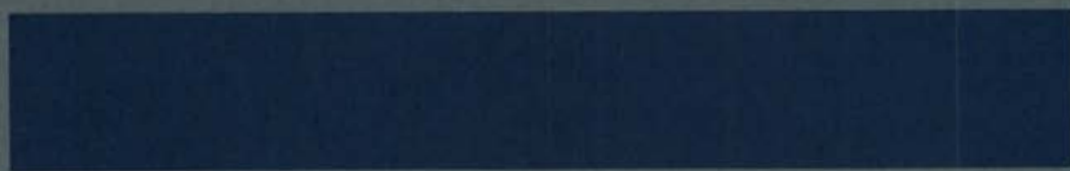

\section{AEC RESEARCH \& DEVELOPMENT REPORT}

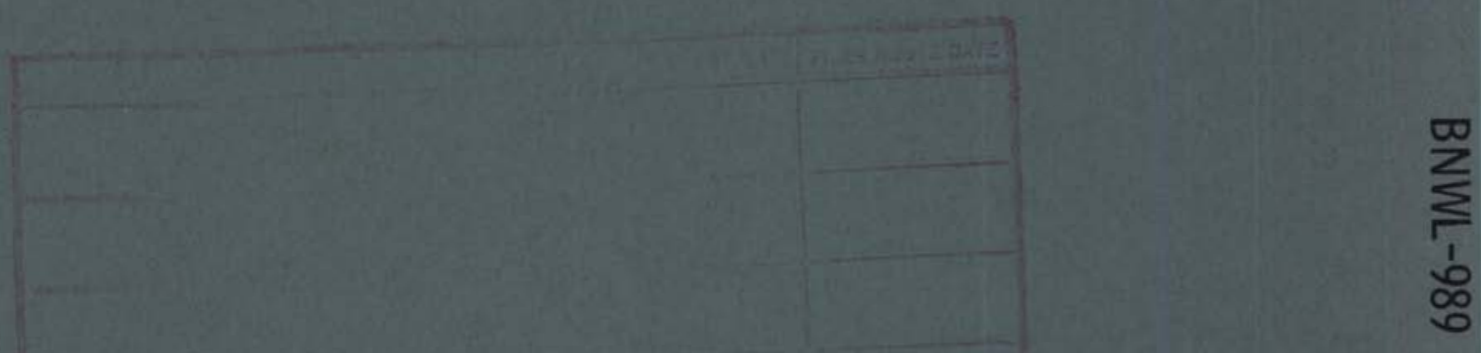




\section{LEGAL NOTICE}

This report was prepared as an account of Government sponsored work. Neither the United States, nor the Commission, nor any person acting on behalf of the Commission:

A. Makes any warranty ar representation, expressed or implied, with respect to the accuracy, completeness, or usefulness of the information contained in this report, or that the use of any information, apparatus, method, or process disclosed in this report may not infringe privately owned rights; or

B. Assumes any liabilities with respect to the use of, or for damages resulting from the use of any information, apparatus, method, or process disclosed in this report.

As used in the above, "person acting on behalf of the Commission" includes any employee or contractor of the Commission, or employee of such contractor, to the extent that such employee or contractor of the Commission, or employee of such contractor prepares, disseminates, or provides access to, any information pursuant to his employment or contract with the Commission, or his employment with such contractor.

\section{PACIFIC NORTHWEST LABORATORY \\ RICHLAND, WASHINGTON \\ operated by \\ BATTELLE MEMORIAL INSTITUTE}

for the

UNITED STATES ATOMIC ENERGY COMMISSION UNDER CONTRACT AT(45-1)-1830 
BNWL - 989

UC-25, Meta1s,

Ceramics, and Materials

\section{THERMAL CONDUCTIVITY AND ELECTRICAL RESISTIVITY}

OF URANIUM OXYCARBIDE

By

J. Lambert Bates

Metallurgy and Ceramics Department

Chemistry and Metallurgy Division

FIRST UNRESTRICTED

DISTRIBUTICON MADE

March 1969

BATTELLE MEMORIAL INSTITUTE

PACIFIC NORTHWEST LABORATORY

RICHLAND, WASHINGTON 99352 
Printed in the United States of America Available from

Clearinghouse for Federal Scientific and Technical Information National Bureau of Standards, U.S. Department of Commerce Springfield, Virginia 22151

Price: Printed Copy $\$ 3.00 ;$ Microfiche $\$ 0.65$ 


\title{
THERMAL CONDUCTIVITY AND ELECTRICAL RESISTIVITY \\ OF URANIUM OXYCARBIDE
}

\author{
J. Lambert Bates
}

\begin{abstract}
The thermal diffusivity $(\alpha)$ of uranium oxycarbide was measured from 100 and $1500{ }^{\circ} \mathrm{C}$ as a function of oxygen concentration from 2 to 17 at. $\%$. Thermal diffusivity decreased as oxygen content increased. Oxycarbides with the lowest oxygen content showed a decrease in $\alpha$ as temperature increased, whereas oxycarbides with the highest oxygen contents exhibited an increase in $\alpha$ as temperature increased. Thermal diffusivities of all specimens approach a common value of $0.05 \mathrm{~cm}^{2} / \mathrm{sec}$ at the high temperatures. Calculated thermal conductivities near $1500{ }^{\circ} \mathrm{C}$ are about $0.18 \mathrm{~W} / \mathrm{cm}^{\circ}{ }^{\circ} \mathrm{C}$, very near the reported values for nearly stoichiometric and slightly hypostoichiometric UC. Electrical resistivity of uranium oxycarbides between room temperature and $1775^{\circ} \mathrm{K}$ increased as oxygen concentration increased from 2 to 16 at. $\%$. Electronic thermal conductivity is predominant above about $1200^{\circ} \mathrm{C}$; phonon conductivity is predominant at lower temperatures and decreases with increasing oxygen content.
\end{abstract}




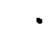

. 
TABLE OF CONTENTS

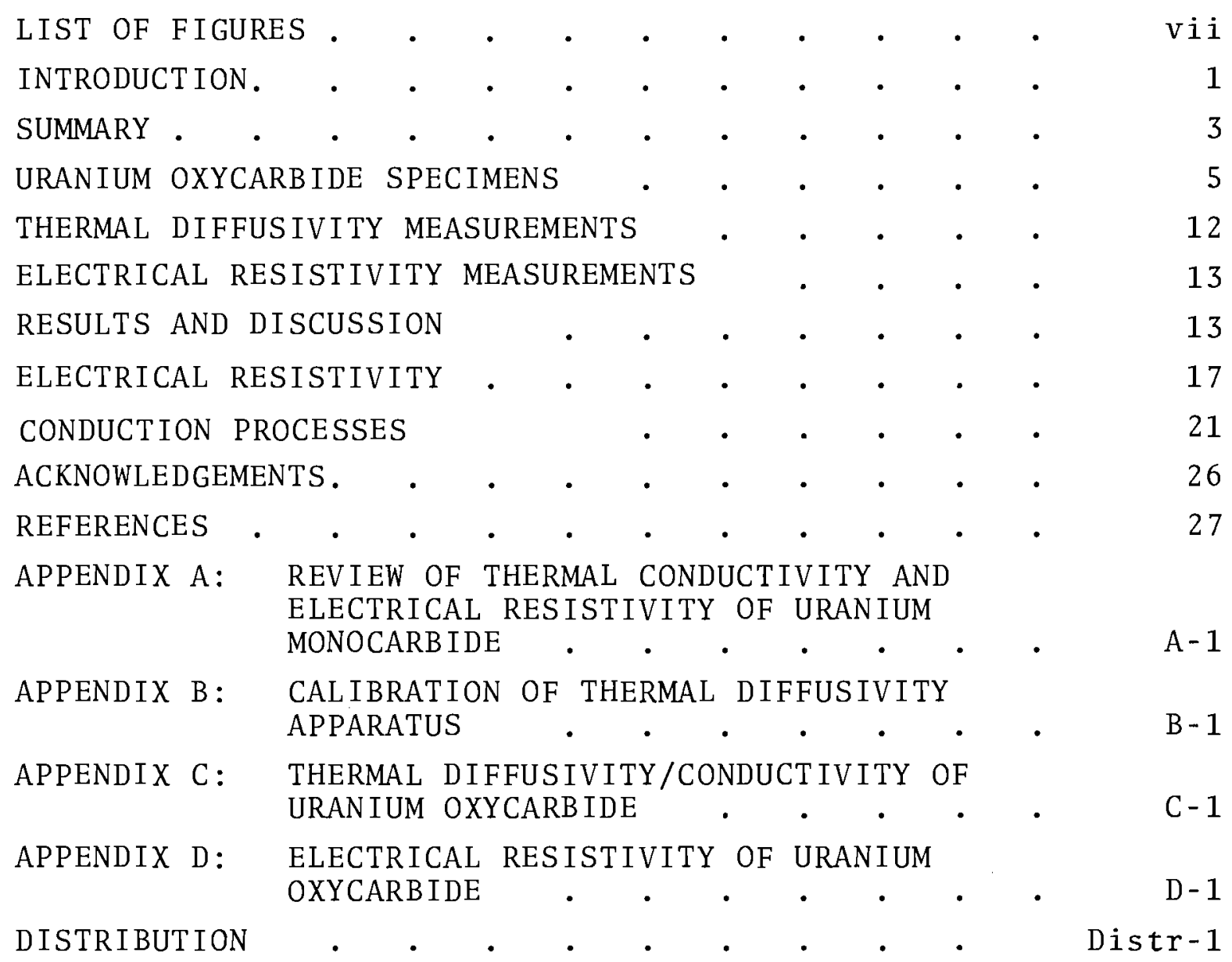


เ 


\section{LIST OF FIGURES}

1 Phases and Phase Relations in the U-C-O System at $1700^{\circ} \mathrm{C}$, Showing Compositions of Uranium Oxycarbide Samples

2 Microstructure of $\mathrm{U}_{0.495^{\mathrm{C}}} 0.485^{\mathrm{O}} 0.02$ (UCON-283) Before and After Thermal Diffusivity Measurements to $1500{ }^{\circ} \mathrm{C}$

3 Microstructure of $\mathrm{U}_{0.48^{\mathrm{C}}} 0.49^{\mathrm{O}} 0.03$ (UCON-365) Before and After Thermal Diffusivity Measurements to $1500{ }^{\circ} \mathrm{C}$

4 Microstructure of $\mathrm{U}_{0.495^{\mathrm{C}}} 0.355^{\mathrm{O}} 0.15$ (UCON-288) Before and After Thermal Diffusivity Measurements to $1500^{\circ} \mathrm{C} \quad 10$

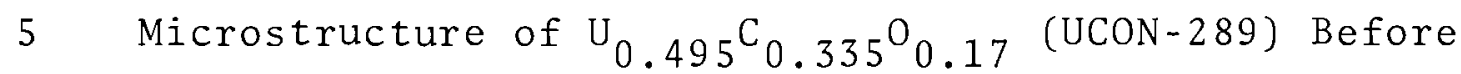
and After Thermal Diffusivity Measurements to $1500{ }^{\circ} \mathrm{C} \quad 11$

6 Thermal Diffusivity of Uranium Oxycarbides

7 Thermal Conductivity of Uranium Oxycarbides Calculated from Thermal Diffusivity Data and Heat Capacity of Uranium Monocarbide

8 Thermal Conductivity of Uranium Oxycarbide Compared with Some Selected Conductivity Values for Uranium Monocarbide (See Appendix A)

9 Electrical Resistivity of Uranium Oxycarbide

10 Electrical Resistivity of Uranium Oxycarbide Compared with Some Selected Resistivity Values for Uranium Monocarbide (See Appendix A)

A-1 A Summary of the Thermal Conductivities of Uranium Monocarbide

A-2 A Summary of the Electrical Resistivities of Uranium Monocarbide

B-1 Therma1 Diffusivity of Armco Iron from 200 to $850{ }^{\circ} \mathrm{C}$ Compared with Reported Thermal Diffusivity Data

B-2 Therma1 Diffusivity of Armco Iron from 680 to $840{ }^{\circ} \mathrm{C} \quad \mathrm{B}-3$

B-3 Percent Deviation of Reported Thermal Diffusivity Data 


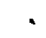

.

, 


\title{
THERMAL CONDUCTIVITY AND ELECTRICAL RESISTIVITY OF URANIUM OXYCARBIDE
}

\author{
J. Lambert Bates
}

\section{INTRODUCTION}

Uranium monocarbide has received considerable attention as a high-temperature fuel for nuclear reactors. Unfortunately, it has been difficult to prepare uranium monocarbide entirely free of oxygen, the oxygen often being found in solid solution in the monocarbide structure. In many studies the presence of small concentrations of oxygen has been ignored, although oxygen, either present in solution or as the oxide, can undoubtedly influence the thermal, electrical, and other properties of the monocarbide. A review of the existing thermal conductivity and electrical resistivity data for UC suggests that the wide scatter in reported thermal conductivity data at low temperatures may be due to differences in the oxygen contents of the carbide (Appendix A).

Recent extensive investigations have been made of the phase relations in the uranium monocarbide region of the uranium-carbon-oxygen system. (1-4) Uranium oxycarbides of desired composition can be prepared as solid solutions with oxygen contents approaching 17 at.\%. Although primarily single phase $\mathrm{UC}_{\mathrm{x}} \mathrm{O}$, the oxycarbide also contains second phases of higher carbides, oxides, and/or metallic uranium.

The purpose of this study was to measure the thermal diffusivity and electrical resistivity of some uranium oxycarbides in the temperature range from 100 to $1500{ }^{\circ} \mathrm{C}$, to calculate thermal conductivity values, and to evaluate the data in terms of electronic and lattice conduction processes. 
. 


\section{SUMMARY}

The thermal diffusivity of uranium oxycarbide was measured from 100 to $1500{ }^{\circ} \mathrm{C}$ as a function of oxygen concentration from 2 to 17 at. $\%$. The thermal diffusivity $(\alpha)$ of the oxycarbides decreased, and the shape of the $\alpha$-versus-T curve changed as the oxygen content increased. Oxycarbides with the lowest oxygen content showed a decrease in $\alpha$ as the temperature increased, whereas the oxycarbides with the highest oxygen content exhibited a slight increase in a with an increase in temperature. The thermal diffusivities of all specimens approach a common value near $0.05 \mathrm{~cm}^{2} / \mathrm{sec}$ at the higher temperatures.

The calculated thermal conductivities of the uranium oxycarbides near $1500{ }^{\circ} \mathrm{C}$ are approximately $0.18 \mathrm{~W} / \mathrm{cm}-{ }^{\circ} \mathrm{C}$, very near the reported values for nearly stoichiometric and slightly hypostoichiometric UC.

The electrical resistivities of uranium oxycarbides containing 2 at. $\%$ and 16 at. $\%$ oxygen were measured from room temperature $1775^{\circ} \mathrm{K}$ to $1500^{\circ} \mathrm{C}$. The electrical resistivity increases as the oxygen concentration increases.

Thermal conduction occurs by both electron and lattice (phonon) processes. The electronic thermal conductivity is predominant above about $1200^{\circ} \mathrm{C}$. The phonon conductivity is predominant at lower temperature and decreases with increasing oxygen content. 
-

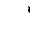




\section{URANIUM OXYCARBIDE SPECIMENS}

The uranium oxycarbide samples were prepared by reaction sintering of calculated quantities of uranium, graphite, and $\mathrm{UO}_{2}$ powders.* The compacts were pulverized and milled to a fine powder in an all-nickel mill under highly purified argon. Pellets were cold pressed and sintered at $1700{ }^{\circ} \mathrm{C}$ for $2 \mathrm{hr}$ in an atmosphere of carbon monoxide at or very near the decomposition pressure for each oxycarbide specimen. Details of the fabrication process have been published by Henry et al. (1)

Ceramographic specimens were mounted in resin and rough ground on dry $3 / 0$ and $2 / 0$ energy papers. The specimens were first polished for $1 \mathrm{hr}$ on a vibratory polisher with $0.3 \mu$ $\mathrm{Al}_{2} \mathrm{O}_{3}$ in water on Metcloth. A final polish was obtained using $20 \mu$ MgO powder in water on Gamal cloth for $1 / 2$ to $1 \mathrm{hr}$. The polished surfaces on some specimens were improved by a 5 sec etching followed by hand polishing with MgO in water. This was repeated if necessary to remove final scratch marks. Specimens were etched in 1:1:1 nitric acid, acetic acid, and water at room temperatures.

The compositions and densities of the uranium oxycarbide specimens are shown in Table 1 . The compositional relationships of each specimen to the reported uranium-carbon-oxygen phase diagram at $1700{ }^{\circ} \mathrm{C}$ are illustrated in Figure 1 .

UCON-283 and UCON-458 ( $\left.\mathrm{U}_{0.495^{\mathrm{C}} 0.485^{\mathrm{O}} 0.02}\right)$ are single phase with minor traces of free uranium and $U_{2}$ (Widmanstätten precipitate)(Figure 2). The relative slow cooling rate during the

* The uranium oxycarbide cylinders for this study were fabricated at the Albany Research Laboratory, United States Bureau of Mines, Albany, Oregon. 
TABLE 1. Description of Uranium oxycarbide Specimens

\begin{tabular}{|c|c|c|c|c|c|}
\hline \multirow[b]{2}{*}{ Designation } & \multicolumn{3}{|c|}{$\begin{array}{c}\text { Composition, } \\
\text { at. } \frac{0}{0}\end{array}$} & \multirow{2}{*}{$\begin{array}{c}\text { Density, } \\
\mathrm{g} / \mathrm{cm} 3 \\
\end{array}$} & \multirow[b]{2}{*}{ Microstructure } \\
\hline & $\overline{\mathrm{U}}$ & $\mathrm{C}$ & $\mathrm{O}$ & & \\
\hline $\mathrm{UCON}-283$ & 49.5 & 48.5 & 2 & 12.7 & $\begin{array}{l}\mathrm{UC}_{\mathrm{X}} \mathrm{O}_{\mathrm{y}} \text { with traces of free } \\
\mathrm{U} \text { and } \mathrm{UC}_{2}\end{array}$ \\
\hline $\mathrm{UCON}-288$ & 49.5 & 35.5 & 15 & 12.5 & $\begin{array}{l}\mathrm{UC}_{\mathrm{X}} \mathrm{O}_{\mathrm{y}} \text { and } \mathrm{UO}_{2} \text { with traces } \\
\text { of free U }\end{array}$ \\
\hline UCON - 289 & 49.5 & 33.5 & 17 & 12.3 & $\begin{array}{l}\mathrm{UC}_{\mathrm{x}} \mathrm{O}_{\mathrm{y}} \text { and } \mathrm{UO}_{2} \text { with traces } \\
\text { of free } \mathrm{U}\end{array}$ \\
\hline UCON -365 & 48.0 & 49.0 & 3 & 13.1 & $\begin{array}{l}\text { Two phase } \mathrm{UC}_{\mathrm{X}} \mathrm{O}_{\mathrm{y}}+\mathrm{UC}_{2} \\
\text { with trace of } \mathrm{UO}_{2} \text {. }\end{array}$ \\
\hline $\mathrm{UCON}-458$ & 49.5 & 48.5 & 2 & 12.75 & $\begin{array}{l}\mathrm{UC}_{\mathrm{x}} \mathrm{O}_{\mathrm{y}} \text { with trace of } \mathrm{UC}_{2} \\
\text { in grain boundaries }\end{array}$ \\
\hline UCON - 459 & 49.5 & 34.5 & 16 & 17.5 & $\begin{array}{l}\mathrm{UC}_{\mathrm{x}} \mathrm{O}_{\mathrm{y}} \text { and } \mathrm{UO}_{2} \text { and trace } \\
\text { of free } \mathrm{U} \text {. }\end{array}$ \\
\hline
\end{tabular}

thermal diffusivity measurements resulted in a slight increase in $U_{2}$ precipitates. The presence of free uranium indicates inhomogeneity on a microscale. Some grain growth appears to have occurred during the measurements.

UCON-365 ( $\left.\mathrm{U}_{0.48} \mathrm{C}_{0.49} \mathrm{O}_{0.03}\right)$ was deliberately made more hyperstoichiometric, resulting in a higher Widmanstätten precipitate of $\mathrm{UC}_{2}$ (Figure 3). A precipitate in the grain boundaries in the etched specimen after the thermal diffusivity measurements is probably secondary sesquicarbide $\left(\mathrm{U}_{2} \mathrm{C}_{3}\right)$.

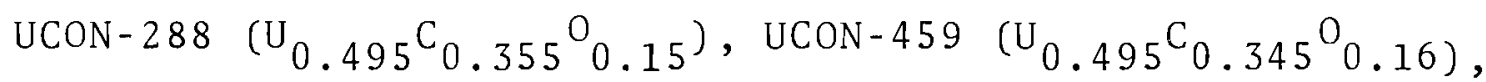
and $\mathrm{UCON}-289\left(\mathrm{U}_{0.495} \mathrm{C}_{0.355^{\circ}} \mathrm{O}_{0.17}\right)$ are two-phase $\mathrm{UC}_{\mathrm{X}} \mathrm{O}_{\mathrm{y}}$ and $\mathrm{UO}_{2}$ with traces of free uranium (Figures 4 and 5 ). The $\mathrm{UO}_{2}$ is the light grey phase, and the free uranium is the white phase in the unetched micrographs. $\mathrm{UO}_{2}$ appears white in the etched specimens. 


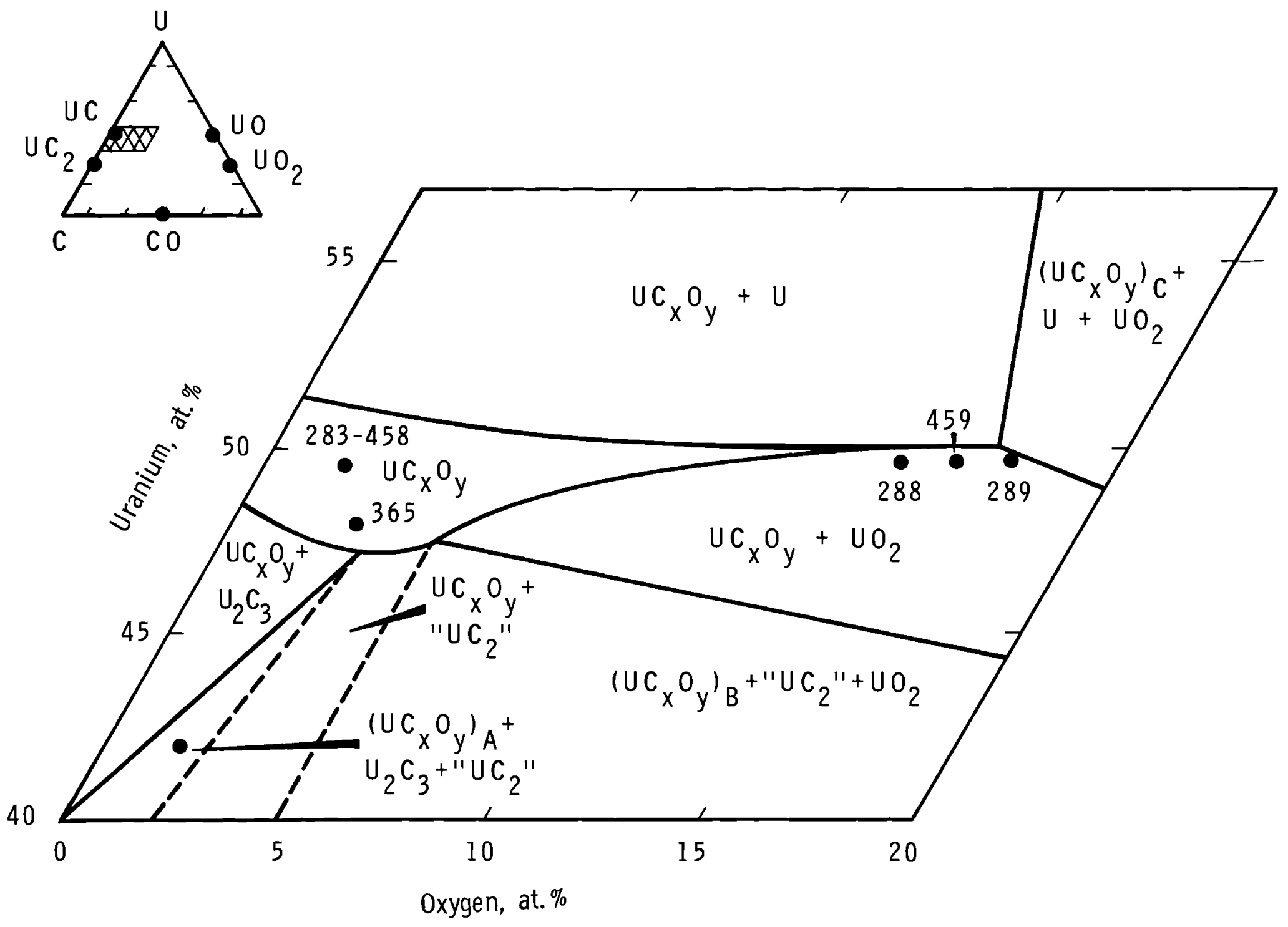

FIGURE 1. Phases and Phase Relations in the U-C-O System at $1700{ }^{\circ} \mathrm{C}$, Showing Composition of Uranium oxycarbide Samples 


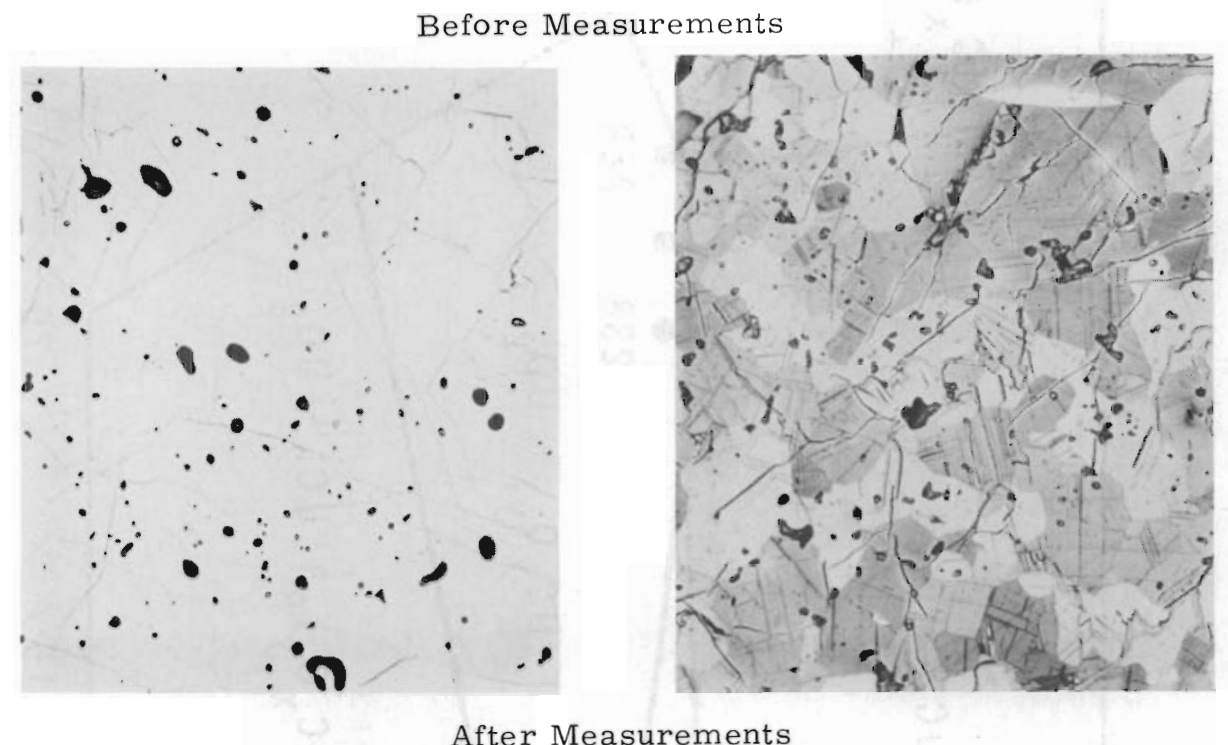

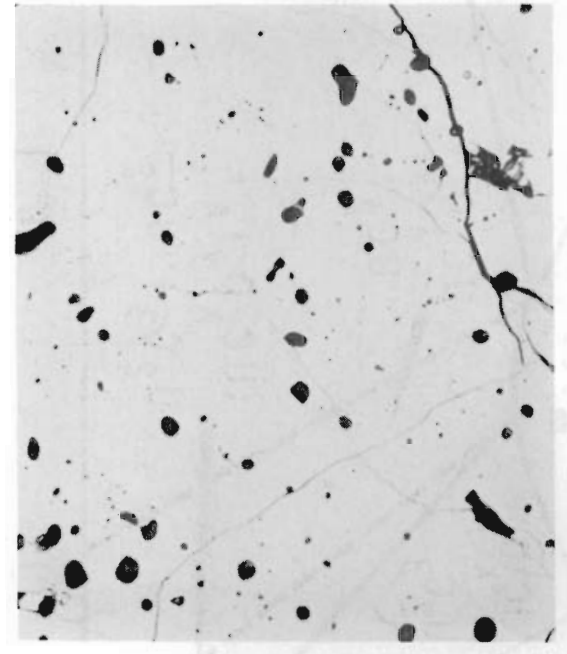

As Polished

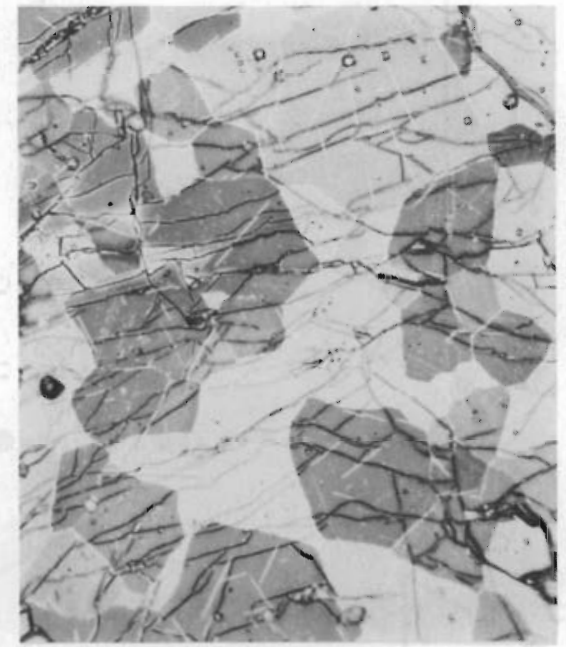

As Etched

Neg $0673132-1$

$300 X$

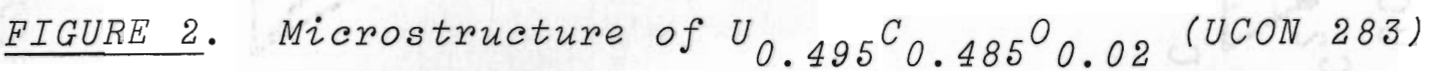
Before and After Thermal Diffusivity Measurements to $1500^{\circ} \mathrm{C}$. The oxycarbide is single phase with a trace of free uranium (white phase). UCON 458 exhibited similar structure. 


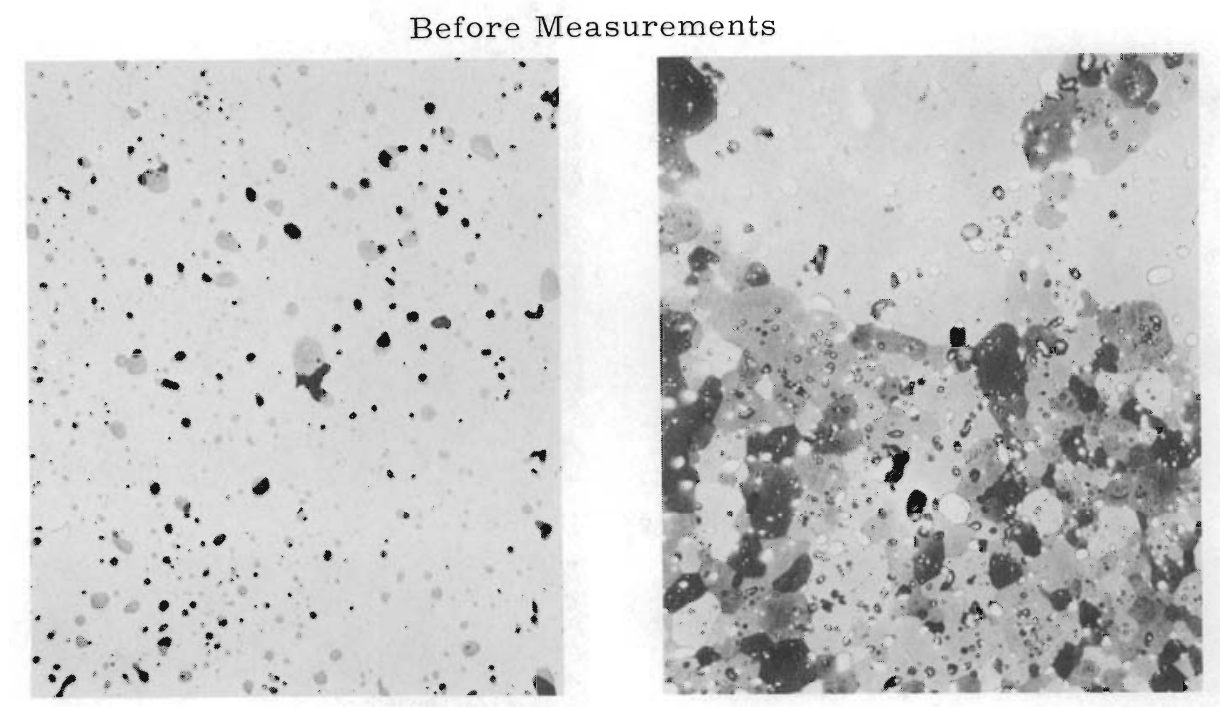

After Measurements

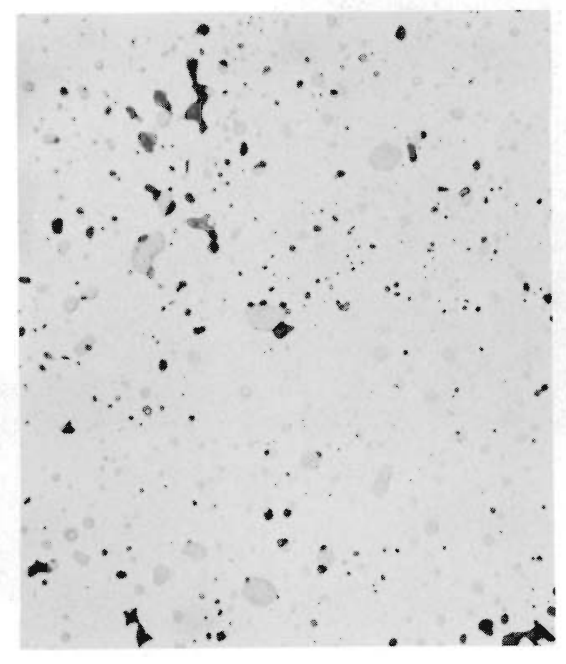

As Polished

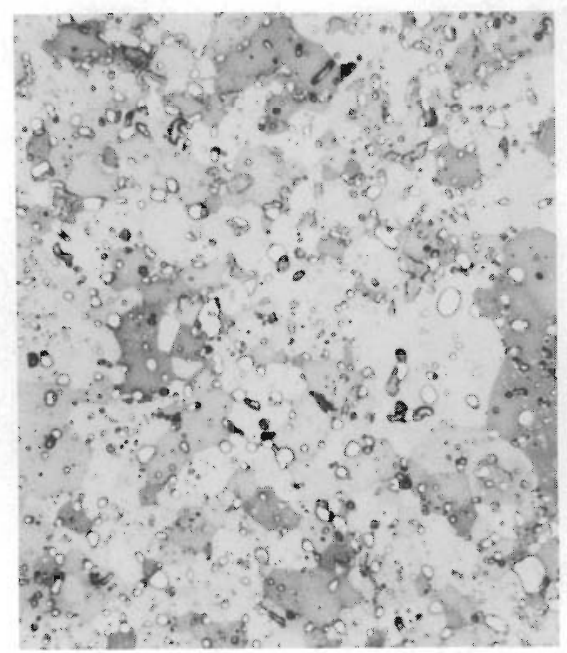

As Etched

Neg $0673132-2$

$300 X$

FIGURE 3. Microstructure of $U_{0.48^{C}} 0.49^{0} 0.03$ (UCON 365) Before and After Thermal Diffusivity Measurements to $1500{ }^{\circ} \mathrm{C}$. The oxycarbide contains a second phase of $U_{2} C_{3}$ (white phase at grain boundaries) and a trace ${ }^{2}$ of $\mathrm{UO}_{2}$ 
Before Measurements
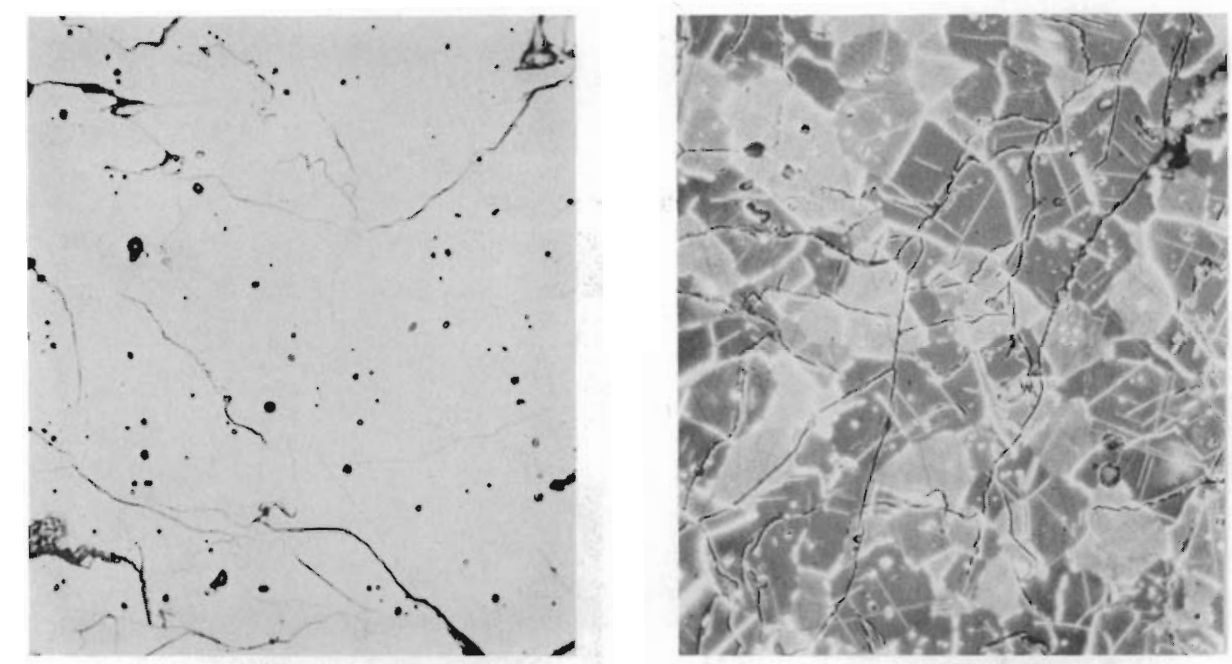

After Measurements

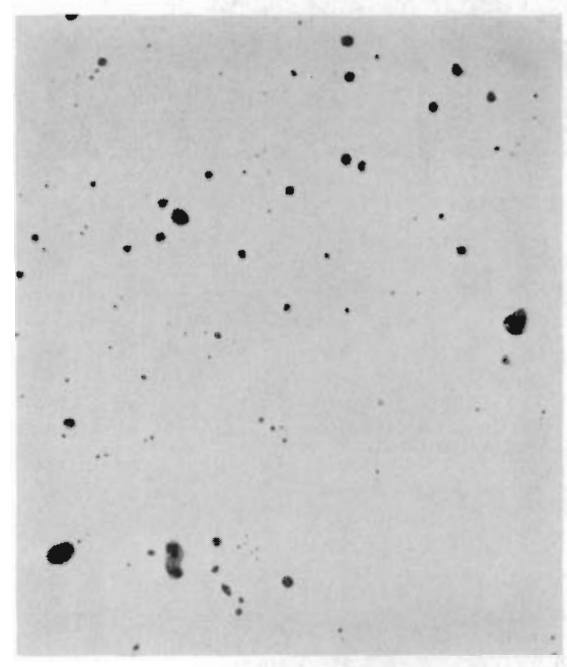

As Polished

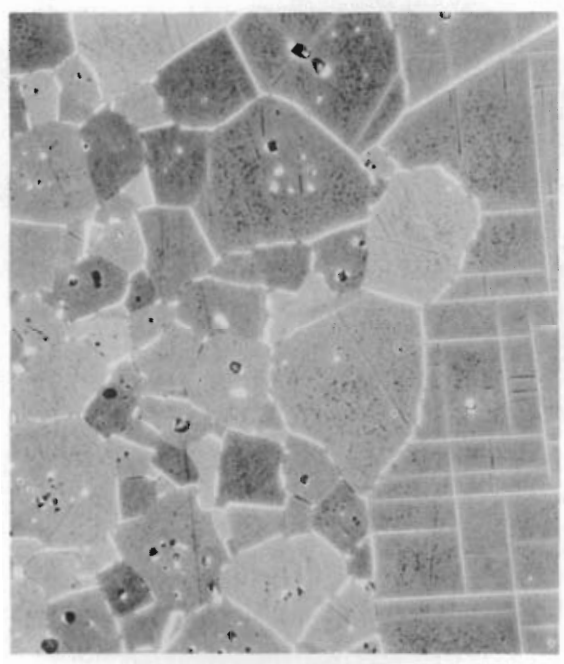

As Etched

Neg $0673132-3$

$300 X$

FIGURE 4. Microstructure of $U_{0.495^{C}} 0.355^{\circ} 0.15$ (UCON288)

Before and After Thermal Diffusivity Measurements to $1500{ }^{\circ} \mathrm{C}$. The oxycarbide is two phase with minor phase of $\mathrm{UO}_{2}$ (grey phase in as-polished and white phase in etched surfaces) and a trace of free uranium (a white phase in as-polished surface). Black areas are pores. $U_{0.495^{C} 0.345^{0} 0.016}$ (UCON-459)

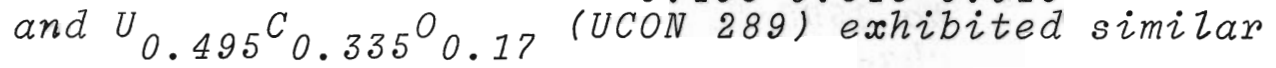
structures. 


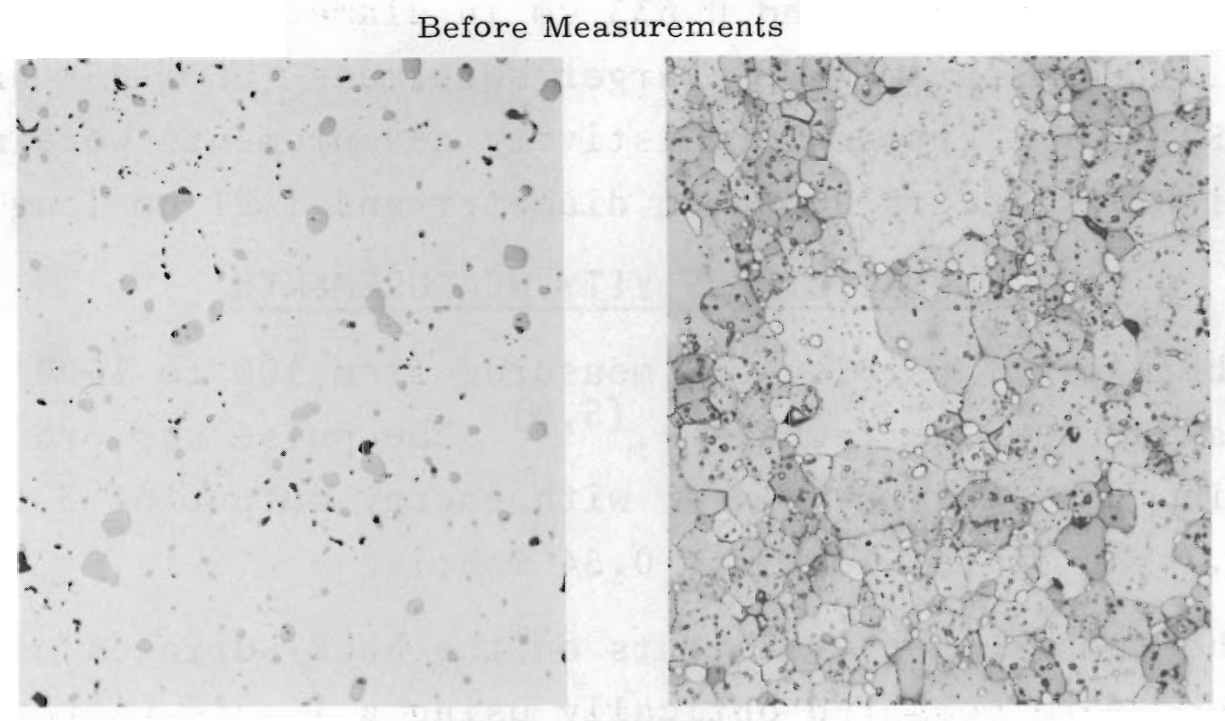

After Measurements

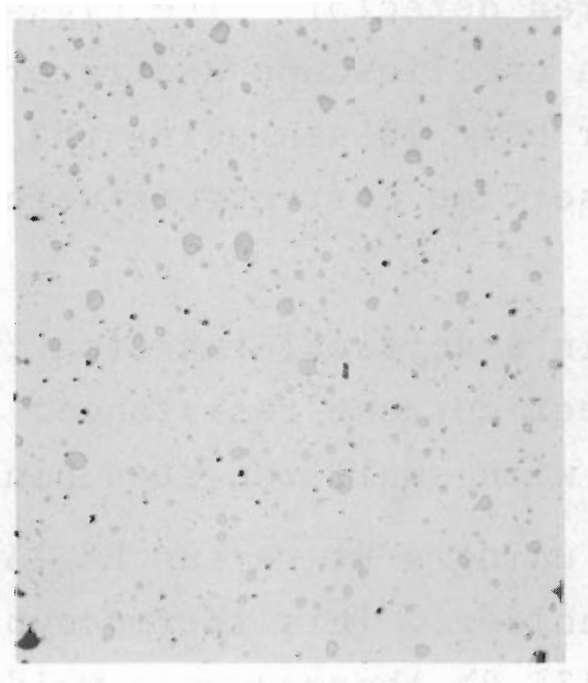

As Polished

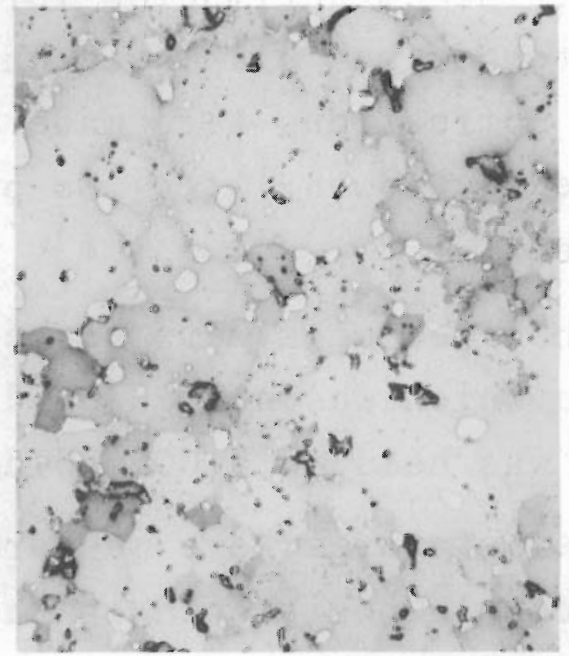

As Etched

FIGURE 5. Microstructure of $U_{0.495^{C} 0.335^{\circ} 0.17}$ (UCON 289) Before and After Thermal Diffusivity Measurements to $1500^{\circ} \mathrm{C}$. The oxycarbide is two phase with minor phase of UO 2 (grey phase in as-polished surface and white phase in etched surface) and a trace of free uranium (white phase in as-polished surface). Black areas are pores. 
The as-fabricated cylinders were cut into thin disks (about $0.100 \mathrm{~cm}$ thick and $0.635 \mathrm{~cm}$ in diameter) for the therma 1 diffusivity measurements. Larger specimens (UCON-458 and UCON-459) for electrical resistivity measurements were machined into right cylinders $0.635 \mathrm{~cm}$ diameter and $1.91 \mathrm{~cm} 1 \mathrm{ong}$.

\section{THERMAL DIFFUSIVITY MEASUREMENTS}

Thermal diffusivity was measured from 100 to $1500^{\circ} \mathrm{C}$ using a laser-pulse technique. $(5,6)$ The pulse was provided by a 0.5 in. diameter ruby laser with energy output of 3 to 7 Joules. The pulse width was $0.54 \mathrm{msec}$.

The temperature transients on the back surfaces of the specimens were measured optically using a liquid nitrogen cooled, indium antimonide infrared detector. The signal from the detector was displayed on an oscilloscope and recorded on film. Corrections were made for heat losses using the method proposed by Cowan. $(7,8)$ No pulse time corrections were required.

The specimens were heated in a vertical tungsten tube furnace which was heated by direct current resistance. The sample was held in a $U_{2}$ holder with small tungsten pins.

Temperatures were measured using a $\mathrm{Pt}$ versus $\mathrm{Pt}-13 \% \mathrm{Rh}$ thermocouple positioned in the holder. This thermocouple was calibrated using another Pt Pt-13\% Rh thermocouple welded to a thin platinum disk set in the sample position. Temperatures were controlled manually.

Measurements were made in purified argon; the inlet argon contained less than 1 ppm oxygen and less than 5 ppm $\mathrm{H}_{2} \mathrm{O}$. The pressure in the furnace was one atmosphere.

Each specimen was heated initial1y to $1000{ }^{\circ} \mathrm{C}$, and thermal diffusivity measurements made during the increase and decrease 
in temperature. Each sample was removed from the furnace to check for possible reaction with the tungsten or $\mathrm{UO}_{2} \cdot$ The specimen was then reinserted in the furnace, and thermal diffusivity measurements were made to approximately $1500^{\circ} \mathrm{C}$. No reactions between the samples and the $\mathrm{UO}_{2}$ or tungsten of the holder were observed.

The thermal diffusivity apparatus was calibrated using ARMCO iron (see Appendix B). The thermal diffusivity data for the iron are in satisfactory agreement with the data reported by Cody et al., (9) Godfrey et al., (10) and Shanks et al. (11)

\section{ELECTRICAL RESISTIVITY MEASUREMENTS}

Electrical resistivity was measured using a four-probe technique which has been successfully used to measure the electrical conductivity of oxides. (12) Measurements were made in purified argon at atmospheric pressure. The inlet argon contained less than 1 ppm oxygen and less than 5 ppm water.

\section{RESULTS AND DISCUSSION}

Thermal diffusivity data for uranium oxycarbide from 100 to $1500{ }^{\circ} \mathrm{C}$ are shown in Figure $6 . *$ The thermal diffusivity $(\alpha)$ of the oxycarbides decreased with increasing oxygen content. This change was most pronounced at the lower temperatures. The diffusivities of the samples containing 15 to 17 at.\% oxygen are approximately $60 \%$ of that for the samples with 2 at.\% oxygen. This difference decreases as the temperature increases.

* The thermal diffusivity and conductivity data for $U C_{x}{ }_{y}$ are tabulated in Appendix $C$. 


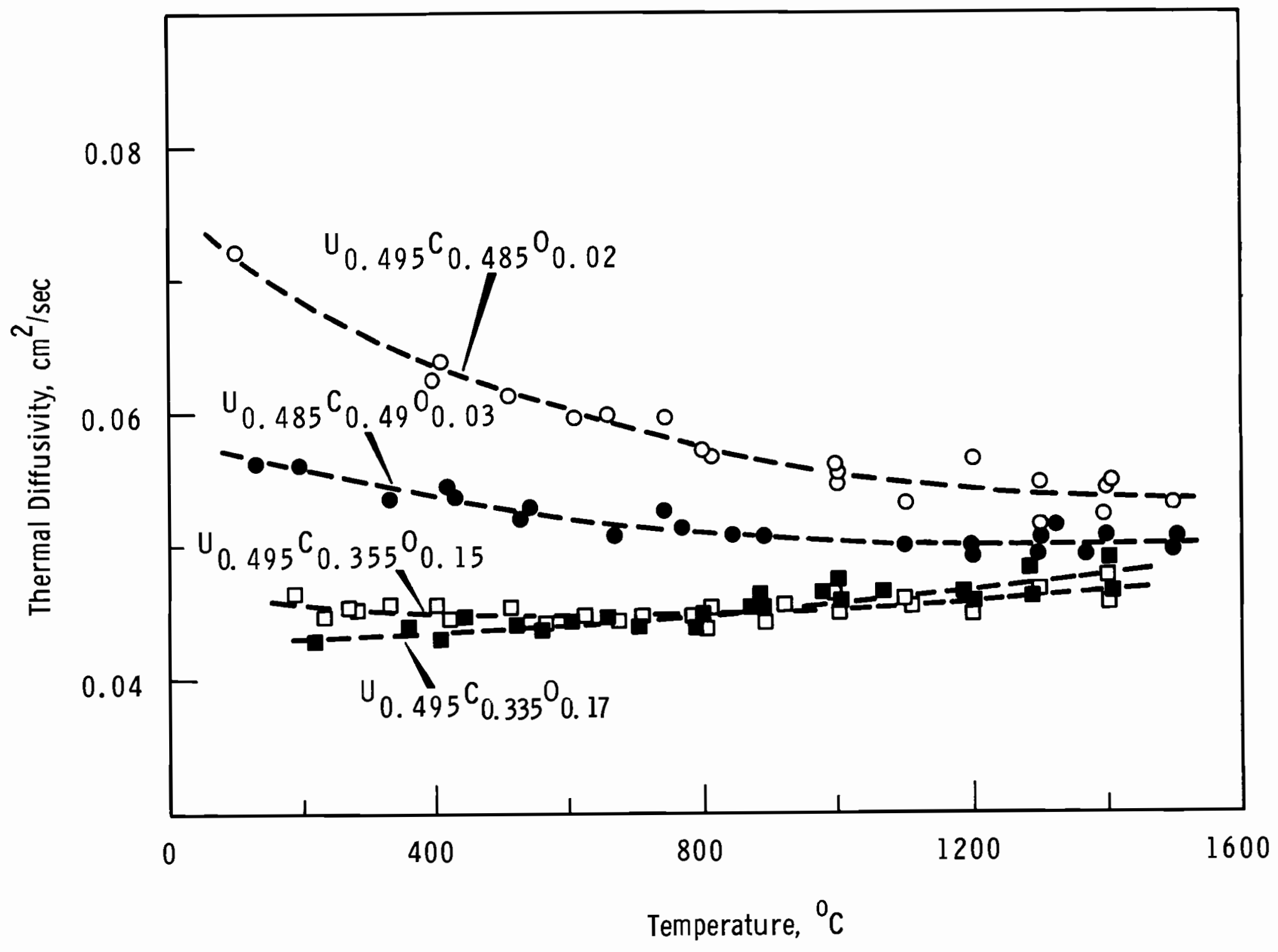


The temperature dependence of the thermal diffusivity varied significantly with oxygen content. The oxycarbides with the lowest oxygen concentration showed a decrease in $\alpha$ as the temperature increased. In contrast, the oxycarbides with the highest oxygen concentration exhibited a slight increase in $\alpha$ with an increase in temperature. The overall result is that the diffusivities of all the specimens approach a common value near $0.05 \mathrm{~cm}^{2} / \mathrm{sec}$ at the higher temperatures.

Thermal conductivities of the uranium oxycarbides* were calculated using heat capacity data for uranium monocarbide. Since the preliminary heat content data of $\mathrm{UC}_{\mathrm{X}} \mathrm{O}_{\mathrm{y}}$ do not differ significantly from that of uranium monocarbide, (13) the heat capacity data reported by Godfrey et al. (14) were used for these calculations. Results are shown in Figure 7 .

The thermal conductivities of the uranium oxycarbides are in fair agreement with the values reported by other investigators for stoichiometric UC with comparable oxygen content (see Appendix A). Comparisons of the thermal diffusivity and conductivity for $\mathrm{UC}_{\mathrm{x}} \mathrm{O}_{\mathrm{y}}$ can best be made using data reported for uranium monocarbides. An analysis must consider not only the oxygen content but also the nitrogen and carbon contents of the monocarbide. It is apparent from this survey that many of the so-called uranium monocarbides actually contain oxygen equivalent to or greater than 2 at. $\frac{0}{\circ}$. Since a few hundred ppm oxygen is equivalent to a significant percent of the total atoms in the carbide ( 1 at. $\%$ is equivalent to approximately $1250 \mathrm{ppm}$ of oxygen), small quantities of oxygen should be expected to affect the thermal conductivity.

* The thermal diffusivity and conductivity data for $U C_{x}{ }_{y}$ are tabulated in Appendix $C$. 


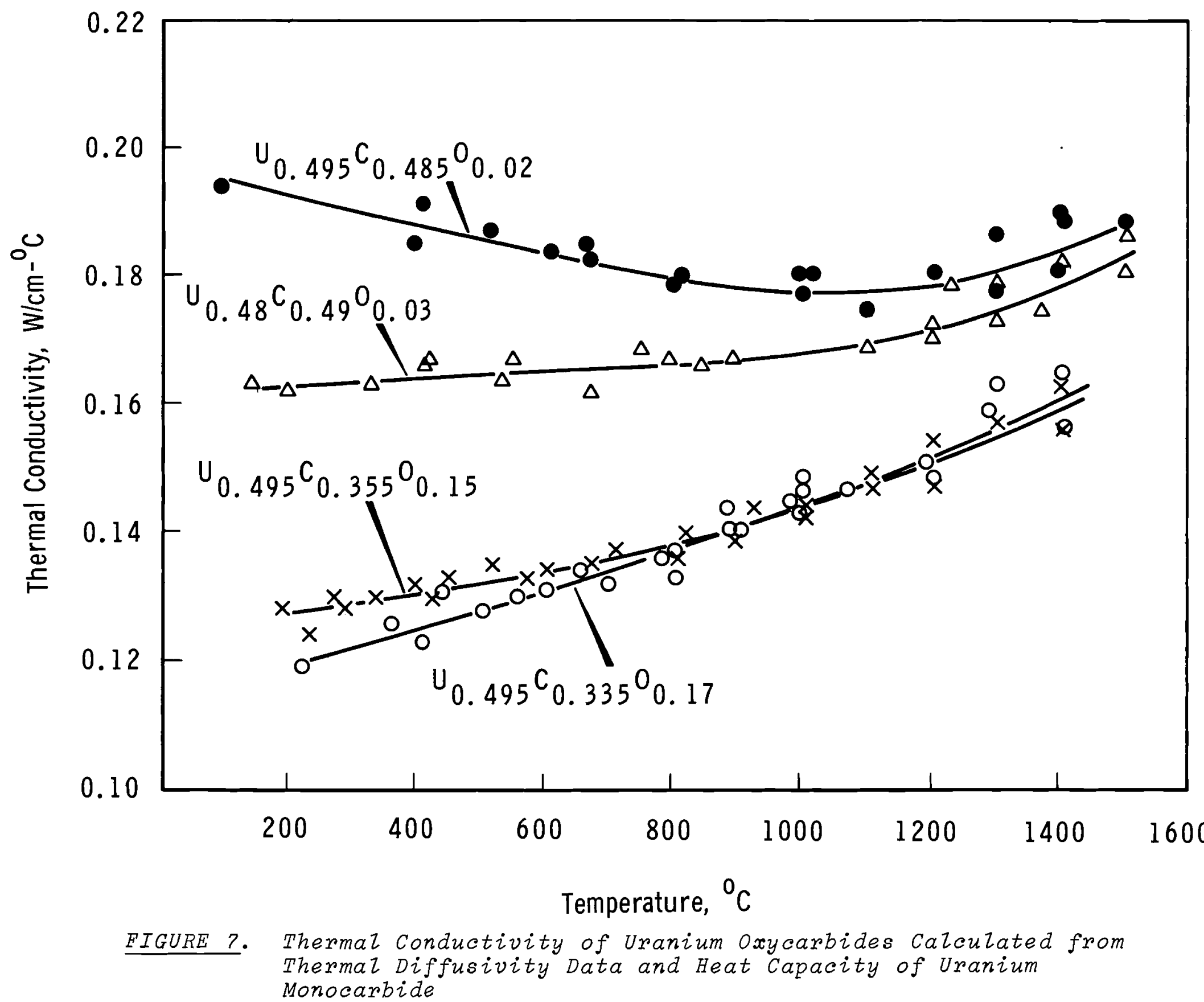


The calculated thermal conductivity values are compared with some selected conductivity values for stoichiometric uranium monocarbides and oxycarbides in Figure 8. Agreement with the values for uranium carbides containing comparable amounts of oxygen is good. The data of Warren and Lacis (19) for an oxycarbide containing 5.3 at. $\%$ oxygen falls between the two values for the oxycarbides with 2 at. $\%$ and 16 at. $\%$

The data of Sobon et a1.(17) and Hayes and DeCrescente (18) exhibit a slight negative temperature coefficient in the same temperature range, with values lower than those for uranium monocarbide. The variations in thermal conductivity are too large to be explained by density differences.

\section{ELECTRICAL RESISTIVITY}

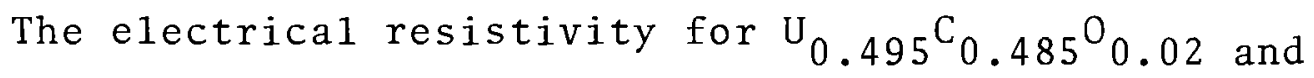
$\mathrm{U}_{0.495^{\mathrm{C}} 0.345^{\mathrm{O}} 0.16}$ increases with increases in temperature (Figure 9).* The electrical resistivity for the oxycarbide containing 16 at. $\%$ is approximately $35 \%$ higher than the resis tivity of the oxycarbide containing 2 at. $\%$ oxygen. The latter oxycarbide also exhibited a slight decrease in resistivity at the lower temperatures after being heated to $1775^{\circ} \mathrm{K}$. No change after heating was observed for the 16 at.\% oxycarbide.

The electrical resistivity of the $\mathrm{U}_{0.495} \mathrm{C}_{0.485^{0}}{ }_{0.02}$ is very close to the resistivities reported for stoichiometric uranium monocarbide (Figure 10). The electrical resistivity for UC is reviewed in Appendix A. Sobon et a1. (17) and Hayes and DeCrescente (18) reported no significant increase in resistivity for UC with an increase in combined oxygen and nitrogen contents

* The electrical resistivity data for $U C_{x} \mathrm{O}_{y}$ are tabulated in Appendix $D$. 


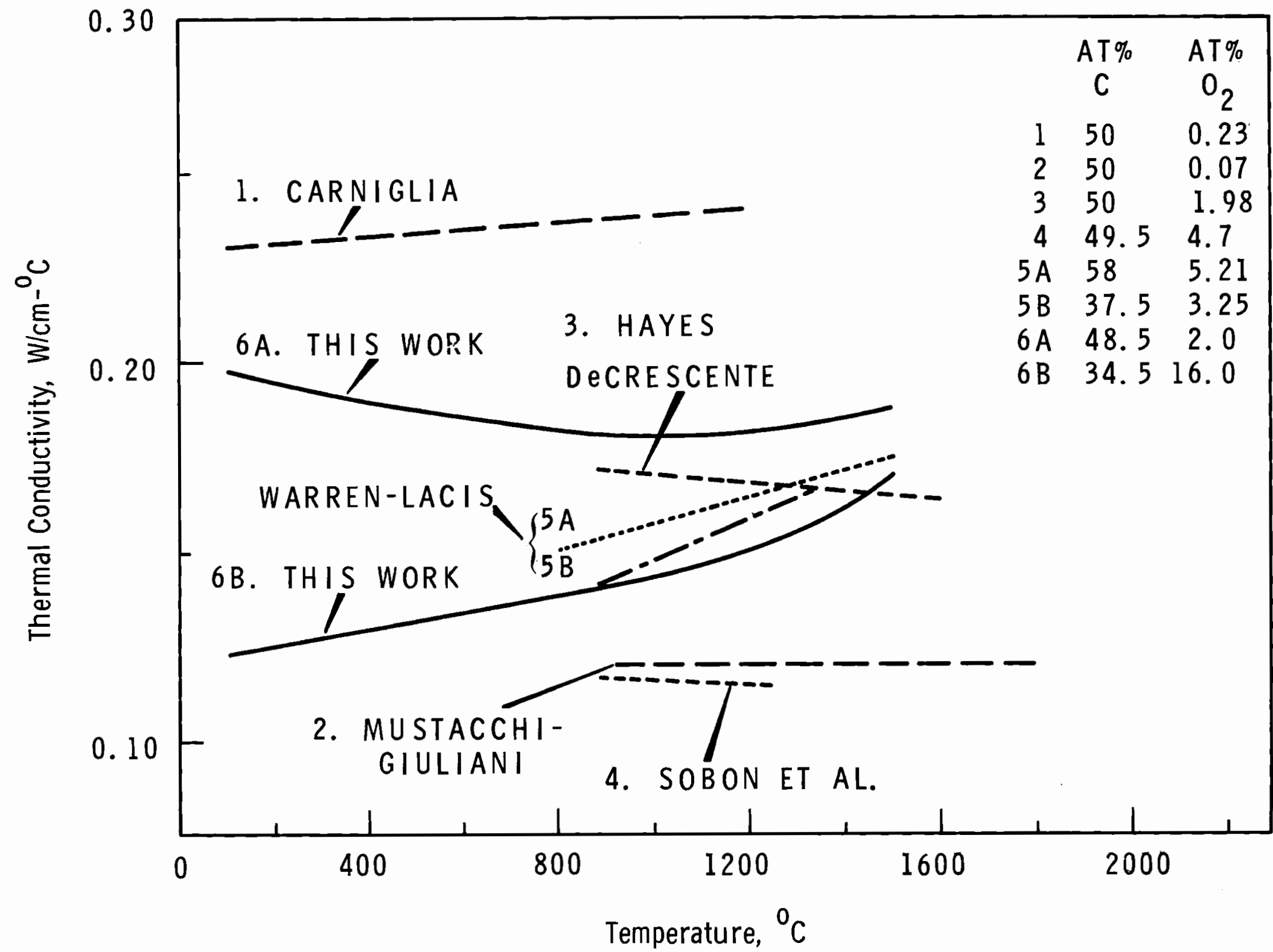

FIGURE 8. Thermal Conductivity of Uranium oxycarbide compared with Some Selected Conductivity Values for Uranium Monocarbide (See Appendix A) 


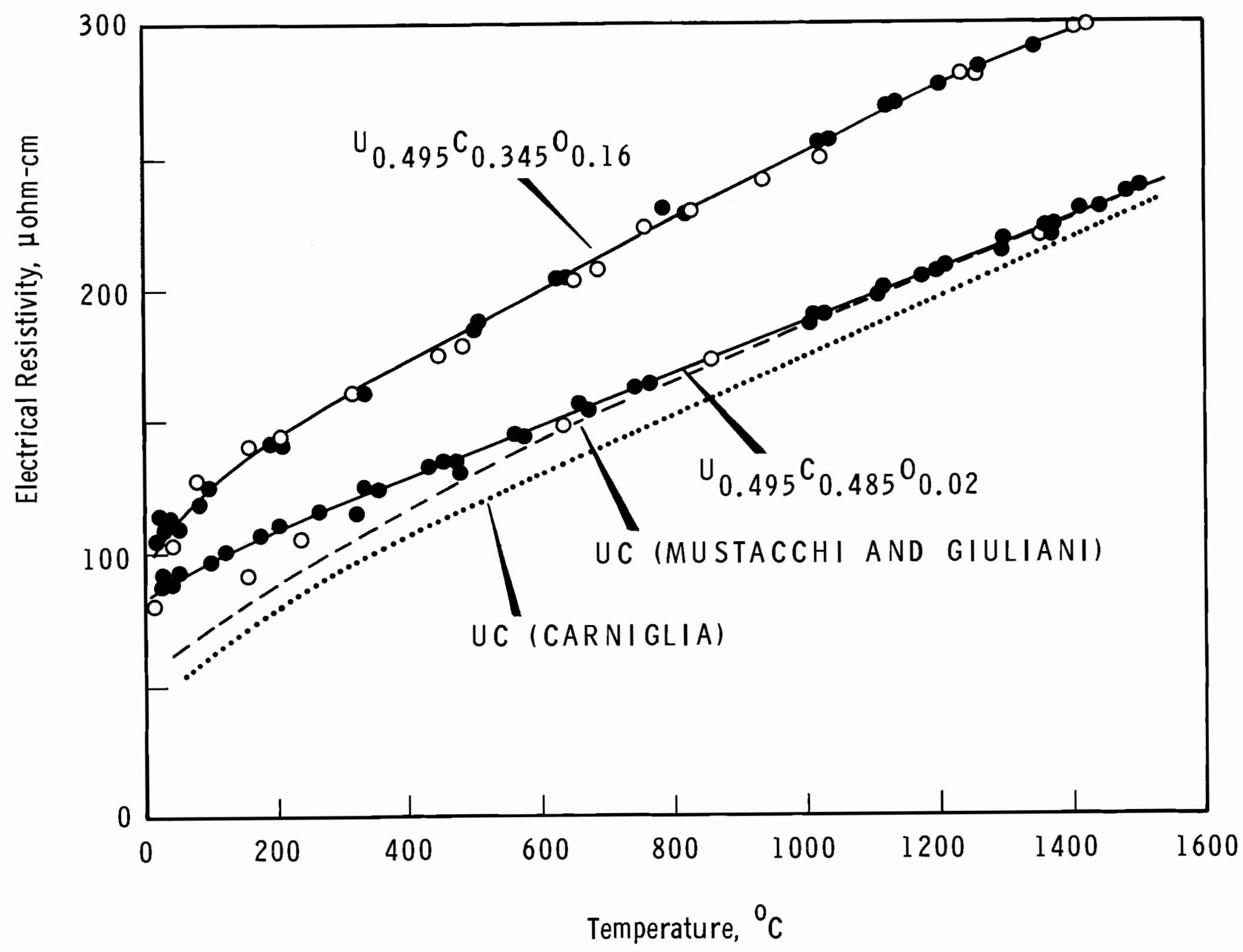

FIGURE 9. Electrical Resistivity of Uranium Oxycarbide 


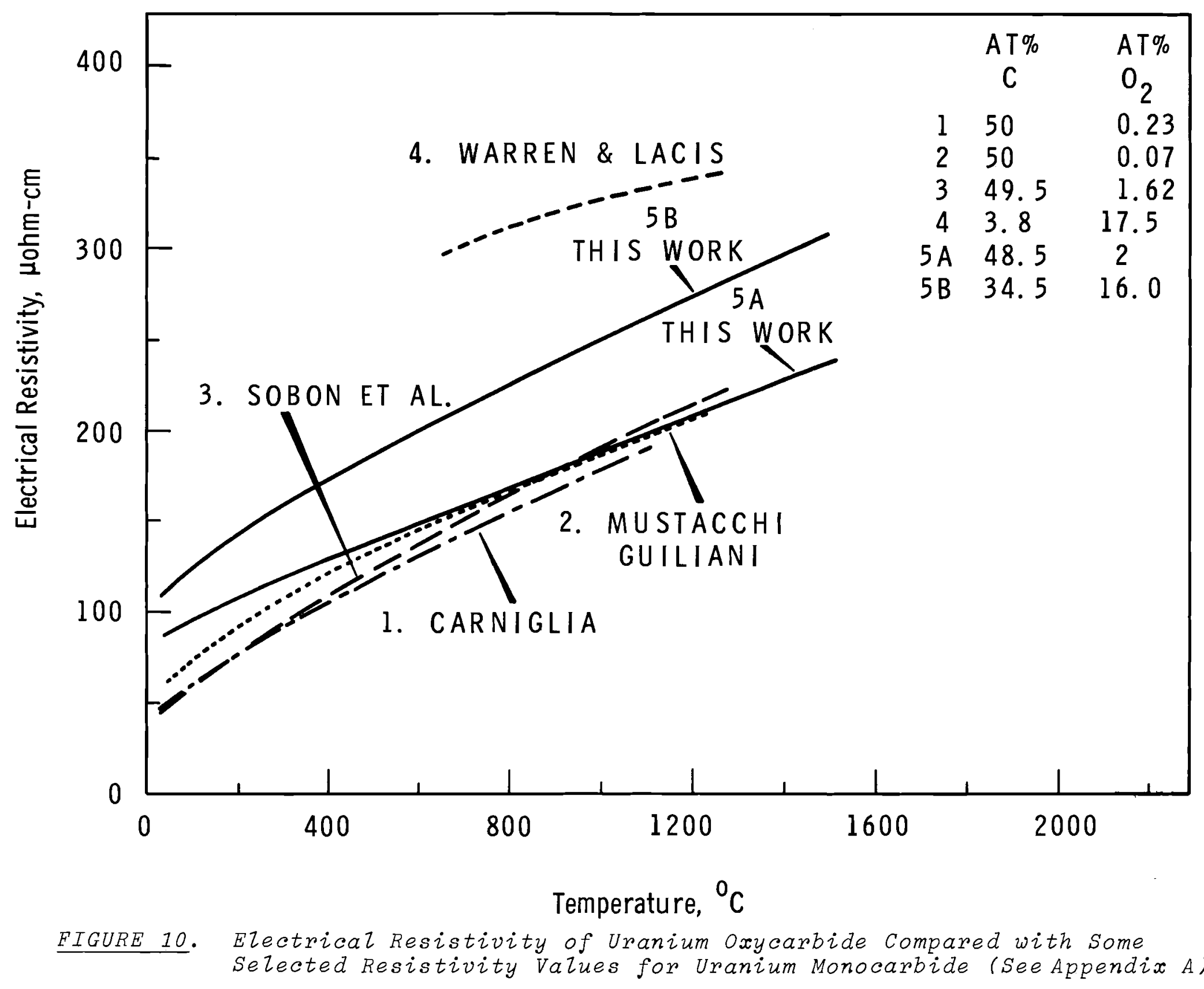


less than approximately 1.75 at. $\%$. However, when the oxygen plus nitrogen content was increased to approximately 3.1 at. $\%$ or above, increases in resistivity were observed. (The oxygen content excluding nitrogen was 1 at.\% and 2 at. $\%$, respectively.) The present results support these previous observations since the resistivity of the $\mathrm{U}_{0} .495^{\mathrm{C}} 0.485^{\mathrm{O}} 0.02$ is very close to the values for UC containing significantly less oxygen.* If, in addition, the resistivities were corrected to a common density, the resistivities would agree more closely with the data of Carniglia, (15) and Mustacchi and Guiliani. (16)

The slope of the resistivity versus temperature curve for

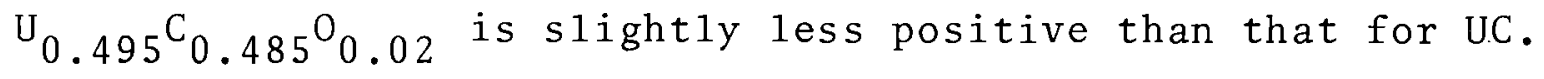
However, the slight increase in slope for the resistivity on cooling makes it agree more closely with the UC data. This suggests that some changes occurred in the oxycarbide at the higher temperatures. However, no variations in the microstructures before and after heating were observed.

The results of this study agree qualitatively with some preliminary electrical property measurement ${ }^{(19)}$ of uranium oxycarbides with oxygen contents between 5 and 7.5 at.\%

(Figure 10).

\section{CONDUCTION PROCESSES}

Heat conduction in carbides occurs partially by electrons and partially by lattice vibrations (phonons). Previous investigators $(16,18,23,25,26)$ have suggested that mixed conduction occurs in uranium monocarbide below $1000{ }^{\circ} \mathrm{C}$; above $1000{ }^{\circ} \mathrm{C}$ conduction is essentially $100 \%$ electronic.

* See Appendix A. 
The total thermal conductivity can be expressed as

$$
\lambda_{\mathrm{T}}=\lambda_{\ell}+\lambda_{\mathrm{e}}
$$

where $\lambda_{\mathrm{T}}$ is the total thermal conductivity, and $\lambda_{\ell}$ and $\lambda_{\mathrm{e}}$ are the lattice and electronic conductivities, respectively. The phonon conductivity in mixed conductors is difficult to measure directly. However, the electronic conductivity can be estimated by means of the Wiedemann-Frantz relationship if the electrical resistivity is known.

The total conductivity can also be expressed as

$$
\lambda_{\mathrm{T}}=\frac{\mathrm{A}}{\mathrm{T}}+\frac{\mathrm{LT}}{\rho}
$$

where $A$ is a constant, $T$ is the absolute temperature, $L$ is the Lorenz number, $\rho$ is the electrical resistivity, and LT/ $\rho$ represents the electronic conductivity.

To evaluate the data, a special curve-fitting program developed at Oak Ridge National Laboratory was employed to analyze the data. (27) A smooth curve for $\lambda$ versus $\mathrm{T}$ was

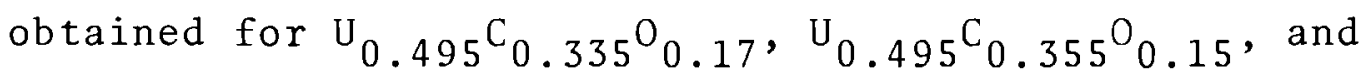
$\mathrm{U}_{0.495^{\mathrm{C}}} 0.485^{\mathrm{O}} 0.02$ using least squares analysis of data. Curves for the 15 and 17 at. $\%$ samples were very close and were treated as one curve with a nominal composition of $\mathrm{U}_{0.495^{\circ} 0.345^{\circ} 0.16^{\circ}}$

Preliminary calculations of $\lambda_{\mathrm{e}}$ using a theoretical Lorenz number $\left(\mathrm{L}_{\mathrm{o}}\right)$ of $2.443 \times 10^{-8}\left(\mathrm{~V} /{ }^{\circ} \mathrm{C}\right)^{2}\left(\lambda_{\mathrm{e}}=\frac{\mathrm{L}_{\mathrm{o}} \mathrm{T}}{\rho}\right)$ indicated that $\lambda_{\mathrm{e}}$ was less than $\lambda_{\mathrm{T}}$ but approached $\lambda_{\mathrm{T}}$ at the higher temperatures.

Smooth curves for $\rho$ versus $T$ were obtained for $\mathrm{U}_{0.495^{\mathrm{C}}} 0.485^{\mathrm{O}} 0.02$ and $\mathrm{U}_{0.495^{\mathrm{C}}} 0.345^{\mathrm{O}} 0.16$ (on heating) and $\mathrm{U}_{0.495^{\mathrm{C}}} 0.345^{\mathrm{O}} 0.16$ (On cooling). 
If Equations (1) and (2) are valid for the oxycarbides, then

$$
\lambda_{\mathrm{T}} \mathrm{T}=\frac{\mathrm{LT}^{2}}{\rho}+\mathrm{A}
$$

A plot of $\lambda T$ versus $\frac{T^{2}}{\rho}$ would be 1 inear, and $L$ and $A$ can then be determined. The results show that for

$$
\begin{aligned}
& \mathrm{U}_{0.495} \mathrm{C}_{0.485^{\mathrm{O}}} 0.02 \\
& \mathrm{~L}=2.71 \times 10^{-8}\left(\mathrm{~V} /{ }^{\circ} \mathrm{C}\right)^{2} \\
& \mathrm{~A}=11.4\left(\mathrm{~W} /{ }^{\circ} \mathrm{C}\right)
\end{aligned}
$$

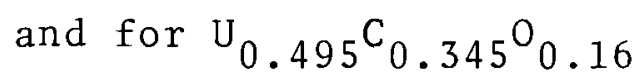

$$
\begin{aligned}
& \mathrm{L}=1.98 \times 10^{-8}\left(\mathrm{~V} /{ }^{\circ} \mathrm{C}\right)^{2} \\
& \mathrm{~A}=54.1\left(\mathrm{~W} /{ }^{\circ} \mathrm{C}\right)
\end{aligned}
$$

The $\lambda_{\mathrm{T}} \mathrm{T}$ versus $\mathrm{T}^{2} / \rho$ curve for $\mathrm{U}_{0.495} \mathrm{C}_{0.485}{ }^{\mathrm{O}} 0.02$ had a break in the curve near $\mathrm{T}^{2} / \rho=3000$ and values of $\mathrm{T}^{2} / \rho$ less than 3000 were ignored.

Seven curve-fitting methods (computerized and least squares) were fitted to the smoothed data for $\mathrm{U}_{0.495} \mathrm{C}_{0.345^{0}} 0.16$ and $\mathrm{U}_{0.495} \mathrm{C}_{0.485^{\circ}} 0.02$ (both heating and cooling). The following equations were considered

$$
\lambda=\frac{L T}{\rho}+\frac{C}{\rho}+\frac{A}{T}
$$

The first two terms allow for an $L$ that decreases with an increase in temperature and the last term for a lattice conduction that decreases with increasing temperature.

$$
\lambda=\frac{L T}{\rho}+\frac{C B}{\rho}+\frac{A}{T}+\frac{B}{T^{2}}
$$

This equation is similar to Equation (4) except an additional term $\frac{\mathrm{B}}{\mathrm{T}^{2}}$ is added to the lattice condition contribution. 


$$
\lambda=\frac{\mathrm{L}_{\max } \mathrm{T}}{\rho}\left[1-\exp \left(-\frac{\mathrm{T}}{\theta}\right)+0.2138\right]+\frac{\mathrm{A}}{\mathrm{T}}+\frac{\mathrm{B}}{\mathrm{T}^{2}}
$$

The first term is an approximation to the theoretically expected behavior for the Lorenz function. The term $\frac{\mathrm{B}}{\mathrm{T}^{2}}$ is chosen to give the minimum standard deviation

$$
\lambda=\frac{\mathrm{L}_{\text {max }} \mathrm{T}}{\rho}\left[1-\exp \left(-\frac{\mathrm{T}}{\theta}\right)+0.2138\right]+\frac{\mathrm{A}}{\mathrm{T}}
$$

This equation is same as Equation (6) with only a single $\frac{A}{T}$ lattice conduction term.

$$
\lambda=\frac{\mathrm{L}_{\max } \mathrm{T}}{\rho}\left[1-\exp \left(-\frac{\mathrm{T}}{\theta}\right)-0.2138\right]
$$

This equation employs no lattice thermal conduction term.

$$
\lambda=\frac{L T}{\rho}+\frac{A}{T}+\frac{B}{T^{2}}
$$

This equation employs a constant Lorenz number, not necessarily equal to $L_{o}$ and two lattice conduction terms

$$
\lambda=\frac{\mathrm{LT}}{\rho}+\frac{\mathrm{A}}{\mathrm{T}}
$$

This equation is similar to Equation (9) but uses only a single lattice conduction term.

The results of this analysis are summarized in Tables 2 and 3 .

For each material, the Lorenz number ( $\mathrm{L}_{,} \mathrm{L}_{\max }$ ) and also the A for all equations are very nearly the same. The increase in the oxygen content increases the value of $\mathrm{L}$, where $\mathrm{L}$ for $\mathrm{U}_{0.495^{\mathrm{C}}} 0.485^{\mathrm{O}} 0.02$ is less than the theoretical Lorenz number $\left(\mathrm{L}_{\mathrm{o}}\right)\left[2.443 \times 10^{-8}\left(\mathrm{~V} /{ }^{\circ} \mathrm{C}\right)^{2}\right]$ which is less than the $\mathrm{L}$ for $\mathrm{U}_{0.495^{\circ}} 0.345^{\mathrm{O}} 0.16^{\circ}$ The increase in oxygen might be analogous to the increase in an alloying element in pure metals, where a similar increase in $L$ is expected. 
TABLE 2. Standard Deviation of Data of Equations (Percent)

\begin{tabular}{|c|c|c|c|}
\hline Equation Number & $\mathrm{U}_{0.495}{ }^{\mathrm{C}} \mathrm{C}$ & $.485^{\mathrm{O}} 0.02$ & $\mathrm{U}_{0.495^{\mathrm{C}} 0.345^{\mathrm{O}} 0.16}$ \\
\hline & (On Heating) & (On Cooling) & \\
\hline 4 & $\begin{array}{l}\text { Fails: negative } \\
\text { lattice term }\end{array}$ & $\begin{array}{l}\text { Fails: negative } \\
\text { lattice term }\end{array}$ & 1.1 \\
\hline 5 & 0.68 & 0.58 & $\begin{array}{l}\text { Fails: negative } \\
\text { electronic term }\end{array}$ \\
\hline 6 & 0.65 & 0.54 & 0.93 \\
\hline 7 & 4.3 & 3.1 & 0.97 \\
\hline 8 & Fails & Fails & Fails \\
\hline 9 & 0.74 & 0.63 & 0.97 \\
\hline 10 & 4.82 & 3.6 & 1.2 \\
\hline
\end{tabular}

TABLE 3. Analysis of Electronic and Lattice Thermal Conductivity of Uranium Oxycarbide

Equation (6)

$A$
$B$
$L_{\max }$

Standard Deviation:

$\Theta$

Equation (9)

A

B

$\mathrm{L}(\operatorname{cons} \tan t)$

Standard Deviation :

Equation (10)
A
$\mathrm{L}$

Standard Deviation:

$$
\frac{\mathrm{U}_{0.495^{\mathrm{C}} 0.485^{\mathrm{O}} 0.02}}{\text { (On Heating) }} \frac{\mathrm{U}_{0.495^{\mathrm{C}} 0.385^{\mathrm{O}} 0.02}}{\text { (On Cooling) }} \quad \mathrm{U}_{0.495^{\mathrm{C}} 0.345^{\mathrm{O}} 0.16}
$$

$$
\begin{array}{ccc}
\lambda=\frac{\mathrm{A}}{\mathrm{T}}+\frac{\mathrm{B}}{\mathrm{T}^{2}}+\frac{\mathrm{L}_{\max } \mathrm{T}^{\mathrm{T}}}{\rho}\left[1-\exp \left(-\frac{\mathrm{T}}{\theta}\right)+0.2138\right] \\
77.54 & 66.05 & 15.95 \\
-9602.1 & -7111.0 & -441.8 \\
1.832 \times 10^{-8} & 1.918 \times 10^{-8} & 2.672 \times 10^{-8} \\
0.54 & 0.65 & 0.93 \\
170^{\circ} \mathrm{K} & 150^{\circ} \mathrm{K} & 80^{\circ} \mathrm{K}
\end{array}
$$

$$
\lambda=\frac{\mathrm{A}}{\mathrm{T}}+\frac{\mathrm{B}}{\mathrm{T}^{2}}+\frac{\mathrm{LT}}{\rho}
$$

$$
\begin{array}{ccc}
75.86 & 65.51 & 16.76 \\
-10,320.0 & -8018.0 & -856.4 \\
1.860 \times 10^{-8} & 1.934 \times 10^{-8} & 2.665 \times 10^{-8} \\
0.74 & 0.63 & 0.97 \\
54.1 & \lambda=\frac{\mathrm{A}}{\mathrm{T}}+\frac{\mathrm{LT}}{\rho} & \\
1.98 \times 10^{-8} & & 11.4 \\
4.82 & & 2.71 \times 10^{-8} \\
& & 1.2
\end{array}
$$


The increase in oxygen content also increases the lattice resistance (as indicated by the decrease in $A$ ) which is indicative of increased phonon scattering with increased oxygen additions.

When Equation 9 is used, the electronic conductivity at

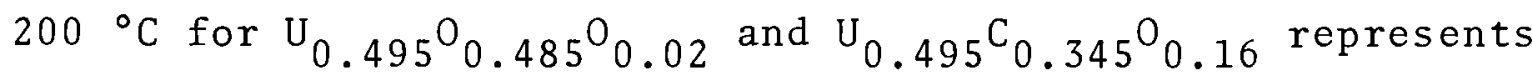
$50 \%$ and $80 \%$ of $\lambda_{\mathrm{T}}$, respectively; at $1500{ }^{\circ} \mathrm{C}$ the electronic conductivity represents $80 \%$ and $95 \%$ of $\lambda_{\mathrm{T}}$, respectively.

Although the analysis of the electrical and thermal conductivities exhibited some quantitative limitations, there is little doubt that mixed conduction does occur in the uranium oxycarbides. It is also apparent from the analysis that the presence of oxygen in the lattice affects the lattice (phonon) conductivity significantly more than it affects the electronic conductivity. The results indicate that although electronic conduction is predominant above $1000{ }^{\circ} \mathrm{C}$, the lattice conduction is still significant, especially in the oxycarbides containing small amounts of oxygen.

\section{ACKNOWLEDGEMENTS}

The author thanks Jack Henry of the United States Bureau of Mines, Albany Metallurgy Research Center, Oregon, for providing the uranium oxycarbide specimens and for the analysis and characterization of the specimens; and D. L. McElroy and his associates at Oak Ridge National Laboratory for the computer analysis of the data. 


\section{REFERENCES}

1. Jack L. Henry, Danton L. Paulson, Robert Blickensdorfer, and Hal $J$. Kelley. Phase Relations in the Uranium Monocarbide Region of the System Uranium-Carbon-Oxygen at $1700{ }^{\circ} \mathrm{C}$, No. 6968. U.S. Bureau of Mines, July 1967.

2. Robert F. Stoops and John V. Hamme. "Phase Relations in the System Uranium-Carbon-Oxygen,"J.Am. Ceram. Soc., vol. 47, no. 2, pp. 59-62. 1964 .

3. Jean-Pierre Morlevat. Contribution a L'Etude du Systeme Uranium-Carbone-Oxygene, CEA-R-2857. Commissarial a I'Energie Atomique, Saclay, France. 1965.

4. P. Chiotte, W. C. Robinson, and M. Kanno. "Thermodynamic Properties of Uranium Oxycarbides," J. Less-Common Metals, vol. 10, pp. 273-289. 1966.

5. W. J. Parker, R. J. Jenkins, C. P. Butzer, and G. L. Abbott. "Flash Method of Determining Thermal Diffusivity, Heat Capacity, and Thermal Conductivity," J. Appl. Phys., vol. 32 , pp. 1679-1684. 1961 .

6. R. L. Rudkins, R. J. Jenkins, and W. J. Parker. "Thermal Diffusivity Measurements on Metals at High Temperatures," Rev. Sci. Instr., vol. 33, pp. 21-24. 1962.

7. R. D. Cowan. "Proposed Method of Measuring Thermal Diffusivity at High Temperature," J. Appl. Phys., vol.32, pp. 1363-1370. 1961 .

8. R. D. Cowan. "Pulse Method of Measuring Thermal Diffusivity at High Temperatures," J. Appl. Phys., vol. 34, pp. 976977. 1963 .

9. G. D. Cody, B. Abeles, and D. S. Beers. "Thermal Diffusivity of Armco Iron," Trans. Met. Soc. AIME, vol. 221, no. 2, p. 25. 1961 .

10. T. G. Godfrey, W. Fulkerson, T. G. Kollie, J. P. Moore, and D. L. MCElroy. Thermal Conductivity of Uranium Dioxide and Armco Iron by an Improved Radial Heat Flow Technique, ORNL3556. Oak Ridge National Laboratory, Oak Ridge, Tennessee, June 1964.

11. H. R. Shanks, A. H. KZein, and G. C. Danielson. "Thermal Properties of Armco Iron," J.Appl. Phys., vol.38, no. 7, pp. 2885-2892. 1967 .

12. J. L. Bates, C. A. Hinman, and T. Kawada. "EZectrical Conductivity of Uranium Dioxide," J.Am. Ceram. Soc., vol. 50, no. $12, p p \cdot 652-656.1967$. 
13. J. L. Henry, R. Blickensdorfer, D. L. Paulsen, and

J. L. Bates. Unpublished Data. Battelle-Northwest, Richland, Washington. (Paper submitted for publication in 1968: Hot Hardness, Heat Capacity, Thermal Conductivity and Electrical Resistivity of Uranium)

14. J. M. Leitnaker and T. G. Godfrey. "Thermodynamic Properties of Uranium Carbides," J. Nucl. Mater., vol. 21, pp. 175-189. 1967 .

15. M. J. Wheeler. "Thermal Conductivity of Uranium Monocarbide," Carbides in Nuclear Energy V-1, Edited by L. E. Russell. Collier-Macmilzan, Limited, London, 1964. pp. $358-365$.

16. C. Mustacchi and S. Guiziani. Development of Methods for the Determination of the High Temperature Thermal Diffusivity of UC, EUR-337. European Atomic Energy Commun$i t y, 1963$.

17. J. T. Sobon, A. D. Milzer, and M. A. DeCrescente. The

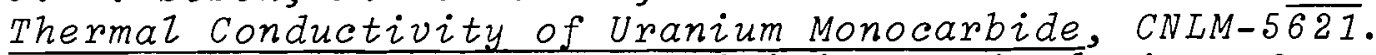
Pratt and Whitney Aircraft Division, United Aircraft Corp., Middletown, Conn., 1964.

18. B. A. Hayes and M. A. DeCrescente. Thermal Conductivity and Electrical Conductivity of Uranium Monocarbide, PWAC-480. Pratt and Whitney Aircraft Division, United Aircraft Corp., Hartford, Conn., 1965.

19. I. H. Warren and J. Lacis. Unpublished Data. University of British Columbia, Vancouver, Canada, October 1967. (Personal Communication)

20. M. A. DeCrescente and A. D. Mizler. "Uranium Carbide at High Temperatures," Carbides in Nuclear Energy V-1, Edited by L. E. Russeli. Collier-Macmilian, Limited, London, 1964. pp. 344-349.

21. S. C. Carniglia. "Single Crystal and Dense Polycrystalline Uranium Carbide: Thermal, Mechanical, and Chemical Properties, Carbides in Nuclear Energy V-I, Edited by L. E. Russeli. Collier-Macmilian, Limited, London, 1964. pp. 407-412.

22. J. B. Moser and O. L. Kruger. "Thermal Conductivity and Heat Capacity of the Monocarbide, Monophosphide and Monosulfide of Uranium," J.Appl. Phys., vol, 38, no. 8, pp. 3215-3222. 1967.

23. R. W. Dayton and C. R. Tipton, Jr. Progress Relating to Civizian Applications During August 1959, BMI-1377, p. 102. Battelle Memorial Institute, Columbus, ohio, September 1959. 
24. P. Costa and $R$. Lallement. "Etude de la structure Electronique des Carbures de Thorium d'Uranium et de Plutonium," J. Phys. Chem. Solid, vol. 25, pp. 559-564. 1964 .

25. L. N. Grossman. "High-Temperature Thermophysical Properties or Uranium Monocarbide," J. Am. Ceram. Soc., vol. 46, no. 6, pp. 264-267. 1963.

26. J.A. Leary, R. L. Thomas, A. E. Ogard, and G. C. Wonn. "Thermal Conductivity and Electrical Resistivity of UC, $(U, P u) C$, and PuC," Carbides in Nuclear Energy V-1, edited by L. E. RusselZ. Collier-Macmillan, Limited, London, 1964. pp. $365-372$.

27. D. E. MCEZroy and R. K. WiZliams. Unpublished Data. oak Ridge National Laboratory, Metals and Ceramics Division, 1968. (Personal Communication) 

APPENDICES 



\section{APPENDIX A}

\section{REVIEW OF THERMAL CONDUCTIVITY AND ELECTRICAL} RESISTIVITY OF URANIUM MONOCARBIDE

The thermal conductivity and electrical resistivity data of nearly stoichiometric UC were reviewed to evaluate possible effects of combined oxygen. Tables A-1 and A-2 list the investigators and references, the compositions, the reported oxygen and nitrogen levels, the densities, the temperature ranges of the measurements, and other information concerning the uranium carbides used by these investigators. The results are also plotted as a function of temperature in Figures A-1 and A-2 with no correction being made for density differences. The review is concerned primarily with stoichiometric UC containing 4.7 to 4.9 wt: carbon. No attempt has been made to evaluate the properties of hypo- or hyperstoichiometric carbides.

\section{THERMAL CONDUCTIVITY DATA}

The thermal conductivity $(\lambda)$ of nearly stoichiometric UC appears to decrease rapidly from room temperature to $500{ }^{\circ} \mathrm{C}$, approaching a constant thermal conductivity value above $500{ }^{\circ} \mathrm{C}$. Above $1200^{\circ} \mathrm{C}$, the thermal conductivity is relatively independent of temperature with a value of approximately $0.17 \mathrm{~W} / \mathrm{cm}^{\circ}{ }^{\circ} \mathrm{C}$.

The scatter in the data at temperatures below $1000{ }^{\circ} \mathrm{C}$ is approximately $\pm 0.065 \mathrm{~W} / \mathrm{cm}^{\circ}{ }^{\circ} \mathrm{C}$ [excluding data of Mihailovic, Howard, (1) and Taylor (19) ]. The scatter above $100{ }^{\circ} \mathrm{C}$ is significantly less, $\pm 0.013 \mathrm{~W} / \mathrm{cm}-{ }^{\circ} \mathrm{C}$.

The following conclusions have been made concerning the thermal conductivity of nearly stoichiometric UC.

(1) $\lambda$ exhibits only a small temperature coefficient above $1000{ }^{\circ} \mathrm{C}(3,7,8,12-15,18)$ with a value at $1000{ }^{\circ} \mathrm{C}$ of approximately $0.17 \mathrm{~W} / \mathrm{cm}^{\circ}{ }^{\circ} \mathrm{C}$. 


\section{TABLE A-1. Summary of Thermal Conductivity for UC}

\begin{tabular}{|c|c|c|c|c|c|c|c|c|c|c|c|}
\hline Investigator & Ref. & $\begin{array}{l}\text { Carbon } \\
\text { Content, } \\
\text { wt: } \\
\end{array}$ & $\begin{array}{l}\text { Oxygen } \\
\text { Content, } \\
\text { ppm } \\
\end{array}$ & $\begin{array}{l}\text { Nitrogen } \\
\text { Content, } \\
\text { ppm } \\
\end{array}$ & $\begin{array}{l}\text { Density, } \\
\mathrm{g} / \mathrm{cm} 3\end{array}$ & $\begin{array}{l}\text { Percent } \\
\quad \mathrm{TD} \\
\end{array}$ & $\begin{array}{l}\text { Temperature } \\
\text { Range, }{ }^{\circ} \mathrm{C} \\
\end{array}$ & $\begin{array}{l}\text { Measured } \\
\text { Thermal } \\
\text { Conductivity, } \\
W / \mathrm{cm}-{ }^{\circ} \mathrm{C} \\
\end{array}$ & $\begin{array}{l}\text { Measuring } \\
\text { Method }\end{array}$ & $\begin{array}{c}\text { Additional } \\
\text { Comments }\end{array}$ & \\
\hline Howard & 1 & NR & NR & NR & $\begin{array}{l}10.03- \\
11.07\end{array}$ & $74-81$ & 60 & 0.134 & $\begin{array}{l}\text { Steady State } \\
\text { Cut Bar }\end{array}$ & 5 points only & \\
\hline $\begin{array}{l}\text { Accary and } \\
\text { Caillat }\end{array}$ & 2 & $\mathrm{NR}$ & $\mathrm{NR}$ & NR & 13.3 & 98 & $119-236$ & $0.180-0.197$ & $\mathrm{NR}$ & $\begin{array}{l}4 \text { points only; } \\
\text { hot pressed UC }\end{array}$ & \\
\hline $\begin{array}{l}\text { Secrest } \\
\text { et al. }\end{array}$ & 3 & 5.2 & NR & NR & 13.63 & 100 & $100-733$ & $0.255-0.222$ & $\begin{array}{l}\text { Steady State } \\
\text { Axial Flow }\end{array}$ & arc cast UC & \\
\hline $\begin{array}{l}\text { Chubb and } \\
\text { Dickerson }\end{array}$ & 6 & $4.8-5.3$ & NR & $\mathrm{NR}$ & $\begin{array}{l}12.5- \\
12.8\end{array}$ & 98 & $100-1000$ & 0.230 & Steady State & $\begin{array}{l}\text { Sintered and arc } \\
\text { cast UC }\end{array}$ & \\
\hline $\begin{array}{l}\text { Mustacchi and } \\
\text { Guiliani }\end{array}$ & 7 & 4.8 & 90 & 500 & 13.63 & 100 & $1100-1700$ & 0.181 & $\begin{array}{l}\text { Therma } 1 \\
\text { Diffusivity }\end{array}$ & $\begin{array}{l}\text { arc cast UC; } \\
\alpha=0.049 \pm \\
0.004 \mathrm{~cm} 2 / \mathrm{sec} \\
\mathrm{Cp}=0.065 \\
\mathrm{cal} / \mathrm{g}-{ }^{\circ} \mathrm{C}\end{array}$ & \\
\hline Grossman & 8 & 5.3 & $\mathrm{NR}$ & $\mathrm{NR}$ & 13.6 & 100 & $875-1775$ & $0.239 \pm 0.008$ & $\begin{array}{l}\text { Special } \\
\text { Technique }\end{array}$ & $\begin{array}{l}\lambda \text { temperature } \\
\text { independent; arc } \\
\text { cast UC }\end{array}$ & $\begin{array}{l}3 \\
1 \\
N\end{array}$ \\
\hline $\begin{array}{l}\text { Dumas and } \\
\text { Mansard }\end{array}$ & 9 & $\begin{array}{l}4.72- \\
4.85\end{array}$ & 600 & 200 & 13.46 & 99 & $20-600$ & $0.322-0.203$ & Steady State & & \\
\hline Kubota et al. & 10 & 4.8 & NR & NR & & 95 & $125-233$ & $0.149-0.205$ & $\begin{array}{l}\text { Steady State } \\
\text { Axial Flow }\end{array}$ & 4 points only & \\
\hline Leary et al. & 11 & 4.8 & NR & NR & 13.6 & 100 & $300-460$ & $0.224-0.228$ & $\begin{array}{l}\text { Steady State } \\
\text { Axial Flow }\end{array}$ & & \\
\hline Wheeler & 12 & $\begin{array}{l}4.8- \\
5.1\end{array}$ & NR & $\mathrm{NR}$ & 13.6 & $94-100$ & $1187-2007$ & $0.139-0.190$ & $\begin{array}{l}\text { Thermal } \\
\text { Diffusivity }\end{array}$ & $\begin{array}{l}\text { Assumed } \mathrm{Cp}=0.05 \\
\mathrm{Ca} 1 / \mathrm{g}-^{\circ} \mathrm{K} \text { at a11 } \\
\text { temperatures }\end{array}$ & \\
\hline Carniglia & 13 & $\begin{array}{l}4.04- \\
4.50\end{array}$ & $200-400$ & $200-400$ & 13.6 & 100 & $100-100$ & $\sim 0.234$ & $\begin{array}{l}\text { Thermal } \\
\text { Diffusivity }\end{array}$ & $\begin{array}{l}\mathrm{Cp}=0.053 \pm \\
0.003 \mathrm{cal} / \mathrm{cm}-{ }^{\circ} \mathrm{C} ; \\
\text { arc cast UC }\end{array}$ & \\
\hline
\end{tabular}




\section{TABLE A-1. (contd)}

\begin{tabular}{|c|c|c|c|c|c|c|c|c|c|c|}
\hline Investigator & $\underline{\operatorname{Re} \underline{.}}$. & $\begin{array}{l}\text { Carbon } \\
\text { Content, } \\
\text { wt\% } \\
\end{array}$ & $\begin{array}{l}\text { Oxygen } \\
\text { Content, } \\
\text { ppm } \\
\end{array}$ & $\begin{array}{l}\text { Nitrogen } \\
\text { Content, } \\
\text { ppm }\end{array}$ & $\begin{array}{l}\text { Density, } \\
\mathrm{g} / \mathrm{cm}^{3}\end{array}$ & $\begin{array}{c}\text { Percent } \\
\text { TD }\end{array}$ & $\begin{array}{r}\text { Temperature } \\
\text { Range, }{ }^{\circ} \mathrm{C} \\
\end{array}$ & $\begin{array}{c}\text { Measured } \\
\text { Thermal } \\
\text { Conductivity, } \\
W / \mathrm{cm}^{\circ}{ }^{\circ} \mathrm{C} \\
\end{array}$ & $\begin{array}{l}\text { Measuring } \\
\text { Method }\end{array}$ & $\begin{array}{c}\text { Additional } \\
\text { Comments }\end{array}$ \\
\hline Sobon et al. & 14 & $\begin{array}{l}4.63- \\
4.85\end{array}$ & $\begin{array}{l}1250- \\
6800\end{array}$ & $93-1400$ & $\begin{array}{l}11.8- \\
12.9\end{array}$ & $\begin{array}{l}86.5- \\
95\end{array}$ & $880-1600$ & $\begin{array}{l}0.176-0.159 \\
(4.85 \text { wt\% C })\end{array}$ & $\begin{array}{ll}\text { Steady State } \\
\text { Radia1 Flow }\end{array}$ & \\
\hline DeCrescente & 15 & 4.85 & 1250 & NR & 12.4 & 91 & $880-1440$ & $0.189-0.175$ & $\begin{array}{l}\text { Steady State } \\
\text { Radial Flow }\end{array}$ & \\
\hline $\begin{array}{l}\text { Wittenberg } \\
\text { and Grove }\end{array}$ & 16 & 4.78 & NR & NR & 13.10 & 96 & $250-1000$ & $\begin{array}{l}0.303 \pm 0.046- \\
0.163 \pm 0.017\end{array}$ & $\begin{array}{l}\text { Thermal } \\
\text { Diffusivity }\end{array}$ & $\begin{array}{l}\text { Cp measured; } \mathrm{UC} \\
\text { contained } 0.1 \text { wt } \\
\mathrm{Ni}, \mathrm{U}_{2} \mathrm{C}_{3}, \mathrm{UO}_{2} \text { and } \\
\mathrm{UC}_{2}\end{array}$ \\
\hline $\begin{array}{l}\text { Hayes and } \\
\text { DeCrescente }\end{array}$ & $\begin{array}{l}18 \mathrm{a} \\
18 \mathrm{~b}\end{array}$ & 4.8 & $\begin{array}{l}860 \\
860- \\
2000\end{array}$ & $\begin{array}{l}520 \\
520- \\
1400\end{array}$ & 12.9 & 95 & $\begin{array}{l}110-1600 \\
880-1600\end{array}$ & $0.175 \pm 0.005$ & $\begin{array}{ll}\text { Steady } & \text { State } \\
\text { Radial Flow }\end{array}$ & Excellent Review \\
\hline Taylor et al. & 19 & NR & NR & NR & 12.9 & 95 & 30 & 0.127 & $\begin{array}{l}\text { Thermal } \\
\text { Diffusivity }\end{array}$ & $\begin{array}{l}\lambda \text { independent of } \mathrm{T} \\
\mathrm{Cp}=0.048 \text { cal/ } \\
\mathrm{g}-{ }^{\circ} \mathrm{C} ; \mathrm{UC} \text { contained } \\
0.1 \text { wt } \mathrm{Ni}\end{array}$ \\
\hline $\begin{array}{l}\text { Moser and } \\
\text { Kruger }\end{array}$ & 20 & 4.8 & 50 & NR & 13.6 & $99+$ & $23-600$ & $0.251-0.167$ & $\begin{array}{l}\text { Thermal } \\
\text { Diffusivity }\end{array}$ & Cp measured \\
\hline $\begin{array}{l}\text { Warren and } \\
\text { Lacis }\end{array}$ & $\begin{array}{l}21 a \\
21 b\end{array}$ & $\begin{array}{l}5.52 \\
3.58\end{array}$ & $\begin{array}{l}4060 \\
7500\end{array}$ & $\begin{array}{l}\mathrm{NR} \\
\mathrm{NR}\end{array}$ & $\begin{array}{l}\mathrm{NR} \\
\mathrm{NR}\end{array}$ & $\begin{array}{l}\mathrm{NR} \\
\mathrm{NR}\end{array}$ & $\begin{array}{l}800-1500 \\
900-1300\end{array}$ & $\begin{array}{l}0.150-0.176 \\
0.145-0.164\end{array}$ & $\begin{array}{l}\text { Steady State } \\
\text { Steady State }\end{array}$ & $\begin{array}{l}\text { High Oxygen } \\
\text { Carbides }\end{array}$ \\
\hline Mihalovic ${ }^{2}$ & 23 & 4.85 & 600 & 200 & 13.46 & 99 & $450-1200$ & $0.235-0.088$ & Steady State & \\
\hline
\end{tabular}

1. Thermal conductivity calculated from thermal diffusivity data $\lambda=\alpha$. Cp. 0. using constant $C_{p}=0.065$ cal $/ g-{ }^{\circ} C$, $\rho=13.6 \mathrm{~g} / \mathrm{cm}^{3}$ and $\alpha=0.049 \mathrm{~cm}^{2} / \mathrm{sec}$. Mustacchi and Guiliani(7) originally used value of $C_{p}^{p}$ much lower than

2. Data of Minalovic reported by Dumas and Mansard. (9) 
TABLE A-2. Summary of Electrical Resistivity of UC

\begin{tabular}{|c|c|c|c|c|c|c|c|c|c|}
\hline Investigator & $\underline{\operatorname{Ref}}$. & $\begin{array}{l}\text { Carbon } \\
\text { Content. } \\
\text { wt: } \\
\end{array}$ & $\begin{array}{c}\text { Oxygen } \\
\text { Content, } \\
\text { ppm }\end{array}$ & $\begin{array}{l}\text { Nitroten } \\
\text { Content, } \\
\text { ppm }\end{array}$ & $\begin{array}{l}\text { Density } \\
\mathrm{g} / \mathrm{cm}^{3} \\
\end{array}$ & $\begin{array}{l}\text { Percent } \\
\text { TD } \\
\end{array}$ & $\begin{array}{r}\text { Temperature } \\
\text { Range, }{ }^{\circ} \mathrm{C} \\
\end{array}$ & \begin{tabular}{c}
\multicolumn{2}{c}{ Measured } \\
Electrical Resistivity \\
$\mu$ ohm-cm at Lowest \\
and Highest Temperature \\
\end{tabular} & $\begin{array}{c}\text { Additional } \\
\text { Comments }\end{array}$ \\
\hline $\begin{array}{l}\text { Accary and } \\
\text { Caillat }\end{array}$ & 2 & NR & NR & NR & 13.3 & 98 & $40-920$ & $20-98$ & \\
\hline $\begin{array}{l}\text { Dayton and } \\
\text { Tipton }\end{array}$ & 4 & $\begin{array}{l}2.2- \\
9.2\end{array}$ & NR & NR & $\begin{array}{l}12.5- \\
12.8\end{array}$ & $92-94$ & 60 & 41 & $\begin{array}{l}\rho \text { as function of car- } \\
\text { bon content }\end{array}$ \\
\hline Griffiths & 5 & 4.8 & Varied & NR & 12.4 & 91 & $375-1000$ & $100-161$ & $\begin{array}{l}\text { [0] changed during } \\
\text { measurement }\end{array}$ \\
\hline $\begin{array}{l}\text { Mustacchi and } \\
\text { Guiliani }\end{array}$ & 7 & 4.8 & 90 & 500 & 13.6 & 100 & $23-1200$ & $60-208$ & $2 \mathrm{ppm} \mathrm{H}_{2}$ \\
\hline Grossman & 8 & 5.3 & NR & NR & 13.6 & 100 & $925-1775$ & $160-260$ & \\
\hline Leary et al. & $\frac{11}{22}$ & 4.8 & NR & NR & 13.6 & 100 & 60 & 69 & Single measurement \\
\hline Carniglia & 13 & $\begin{array}{l}4.15- \\
9.1\end{array}$ & 180 & NR & 13.6 & 100 & $23-1100$ & $\left.\begin{array}{rl}45-185 & \\
(4.80 \mathrm{wt} & \mathrm{C}\end{array}\right)$ & \\
\hline Sobon et al. & 14 & $\begin{array}{l}4.67- \\
4.77\end{array}$ & $\begin{array}{l}1650- \\
5600\end{array}$ & $\begin{array}{l}170- \\
5600\end{array}$ & $\begin{array}{l}10.7- \\
12.6\end{array}$ & $79-93$ & $21-1308$ & $\begin{array}{l}43-225 \\
(4.77 \text { wt: } \\
\text { C } 93 \% \text { TD })\end{array}$ & \\
\hline $\begin{array}{l}\text { Costa and } \\
\text { Lallement }\end{array}$ & 17 & 4.8 & NR & NR & NR & NR & $-269-925$ & $47-24{ }^{\circ} \mathrm{C}$ & \\
\hline $\begin{array}{l}\text { Hayes and } \\
\text { DeCrescente }\end{array}$ & 18 & 4.8 & $\begin{array}{l}815- \\
2100\end{array}$ & $\begin{array}{l}150- \\
1200\end{array}$ & $\begin{array}{l}11.2- \\
12.4\end{array}$ & $82-91$ & $23-1300$ & $\begin{array}{c}43-215 \\
(91.4 \div \mathrm{TD})\end{array}$ & Excellent Review \\
\hline $\begin{array}{l}\text { Warren and } \\
\text { Lacis }\end{array}$ & 21 & $\begin{array}{l}3.58- \\
5.52\end{array}$ & $\begin{array}{l}4060- \\
7500\end{array}$ & NR & $\mathrm{NR}$ & NR & $375-130$ & & \\
\hline
\end{tabular}




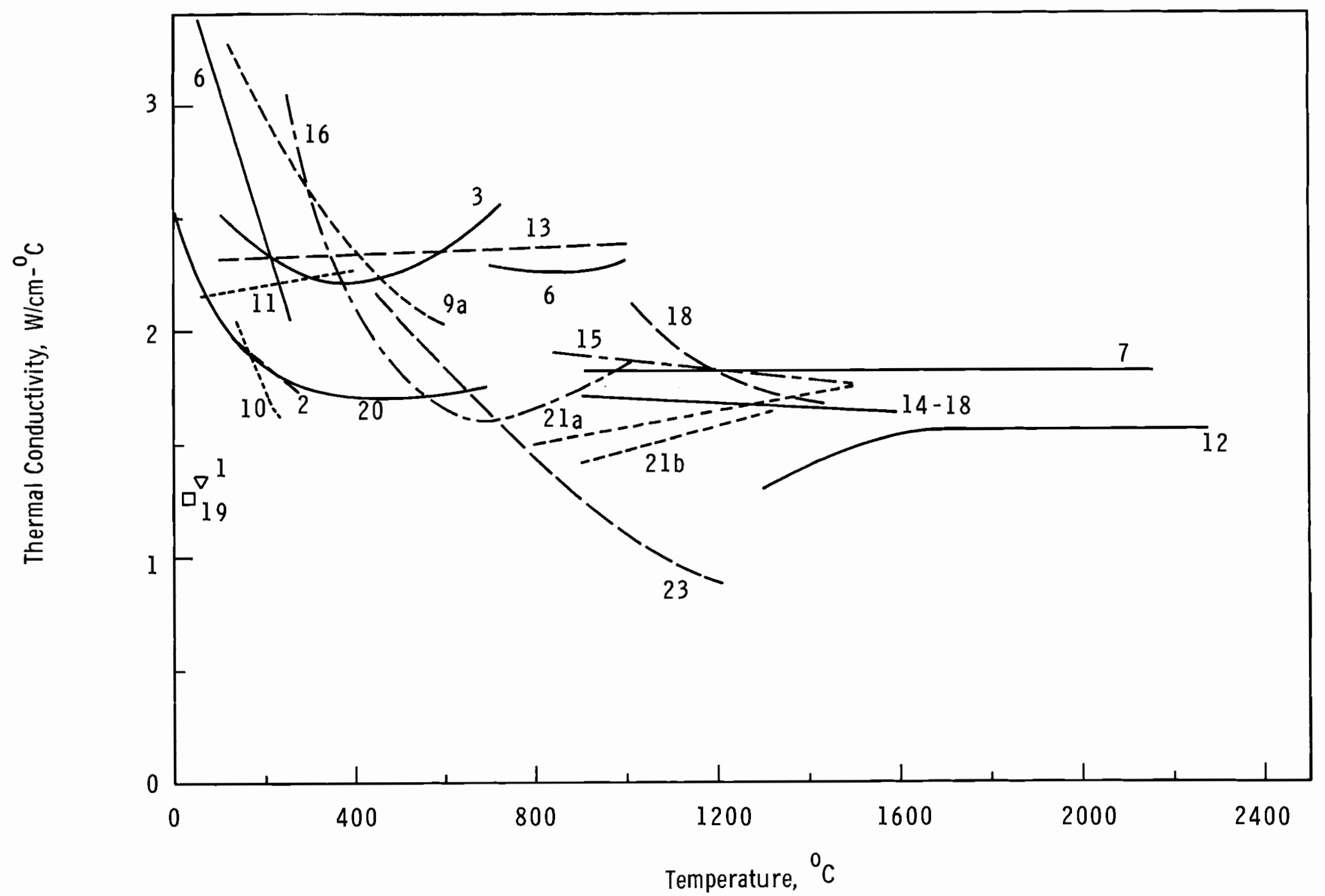

FIGURE A-1. A Summary of the Thermal Conductivities of Uranium Monocarbide 


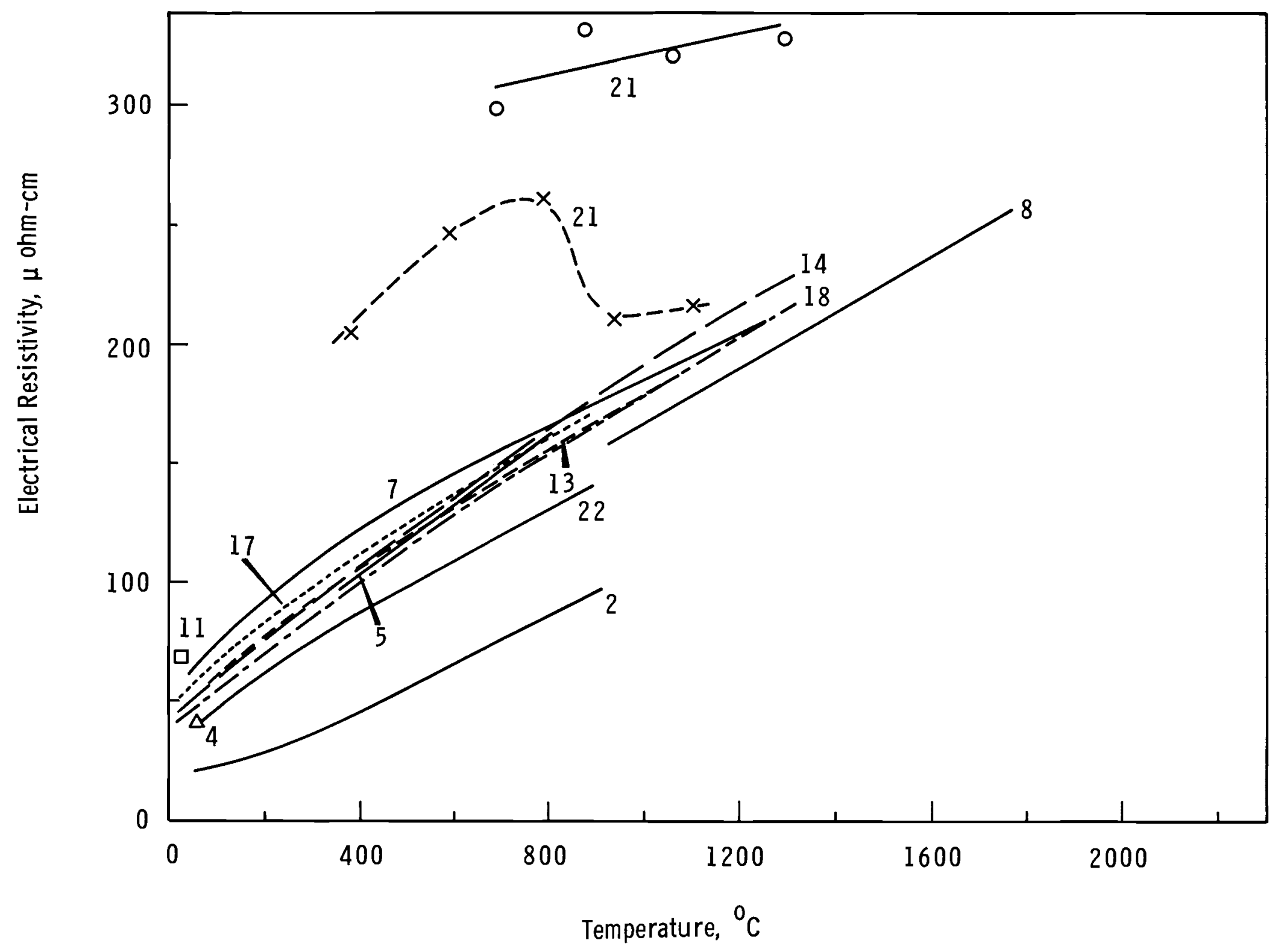

FIGURE A-2. A Summary of the Electrical Resistivities of Uranium Monocarbide 
(2) The thermal conductivity increases with an increase in carbon content. $(6,13)$ Wheeler is the only investigator to observe the opposite effect. (12)

(3) The thermal conductivity decreases as the oxygen content in the UC increases. $(14,15,18,21)$ sobon et a1., (14) DeCrescente and Miller, (15) and Hayes and DeCrescente ${ }^{(18)}$ indicate that the effect of combined oxygen and nitrogen in UC (below $2180 \mathrm{ppm}$ ) is minor, especially at the higher temperatures, with a general lowering of the conductivity when the oxygen was increased from 1380 to $4000 \mathrm{ppm}$. The data suggest that much of the wide scatter in thermal conductivity values at low temperatures could possibly result from variations in oxygen content in UC.

(4) The portion of thermal conductivity due to an electronic process was observed to approach $100 \%$ above $1000^{\circ} \mathrm{C} .(7,8,13-16,18)$

\section{ELECTRICAL RESISTIVITY}

The electrical resistivity of UC increases with increasing temperature. With the exception of the data reported by Accary and Caillat ${ }^{(2)}$ and Leary et al. $(11,22)$ the data fall within a scatter of $\pm 8.5 \mu \mathrm{ohm}-\mathrm{cm}$.

The following conclusions were made concerning the electrical resistivity of nearly stoichiometric UC:

(1) The electrical resistivity increases with temperature and is approximately a linear function of temperature above $500^{\circ} \mathrm{C}$. The temperature coefficient is greater below $500{ }^{\circ} \mathrm{C}$.

(2) The resistivity increases with increasing carbon content. $(4,13)$ A slight increase is observed from pure uranium to $4.8 \mathrm{wt} \%$ carbon and a logrithmic increase from 4.8 to 9.1 wt\% carbon. 
(3) The electrical resistivity increases with increases in both oxygen content and combined oxygen nitrogen content. $(14,18,21)$ Hayes and DeCrescente ${ }^{(18)}$ indicated that resistivity is relatively insensitive to a combined oxygen and nitrogen content to $2300 \mathrm{ppm}$. However, effects are observed when the oxygen content is significantly larger. (21)

(4) The resistivity varies with density by the relationship

$$
\rho_{\mathrm{HD}}=\rho_{\mathrm{LP}}(1-\mathrm{P})^{1.38}
$$

where $\rho_{H D}$ is the high density, $\rho_{L D}$ is the low density and $P$ is the porosity fraction. (18) 


\section{REFERENCES}

1. V. C. Howard. Thermal Conductivity of Uranium Monocarbide, IGR-TM/C-0164. United Kingdom Atomic Energy Authority, Culcheth Laboratories, Culcheth, Lancs, England, May 1958.

2. A. Accary and R. Caizzat. "Development of Ceramic Fuels in France," Nuclear Fuel Elements, edited by H. H. Hausner and $J . F$. Schumar. Reinhold Publishing Corp., New York, 1959. pp. 257-266.

3. A. C. Secrest, Jr., E. L. Foster, and R. F. Dickerson. Preparation and Properties of Uranium Monocarbide Castings, BMI-1309. Battelie Memorial Institute, Columbus, ohio, January 2, 1959.

4. R. W. Dayton and $C$. R. Tipton, Jr. Progress Relating to Civilian Application During June 1959, BMI-1357, p. 53. Battelze Memorial Institute, Columbus, ohio, July 1, 1959.

5. L. B. Griffiths. "Effect of Oxygen on the Temperature Coefficient of Resistivity of Uranium Monocarbide," Nature, vol. 193, no. 4813, p. 362. 1962.

6. W. Chubb and R. F. Dickerson. "Properties of Uranium Carbide," Am. Cer. Soc. Bulz., vol. 41, no. 9, pp. 564569. 1962 .

7. C. Mustacchi and S. Guiziani. Development of Methods for the Determination of the High Temperature Thermal Diffusivity of UC, EUR 337.e. European Atomic Energy Community, 1963 .

8. L. N. Grossman. "High Temperature Thermophysical Properties of Uranium Monocarbide," J.Am. Cer. Soc., vol. 46, no. 6, pp. 264-267. 1963.

9. J. P. Dumas and B. Mansard. Conductivite Thermique du Monocarbure d'Uranium, EURAEC-1173. Avaizable from Clearinghouse for Federal Scientific and Technical Information, Lynchburg, Va., 1964.

10. T. Kubota, y. Seki, and S. Takahashi. "Thermal Conductivity of $U O_{2}$, UC, and UCZ," J.Nucl. Sci.Tech., vol. 1, no. 3, pp. $93-100$. 1964.

11. J. A. Leary, R. L. Thomas, A. E. Ogard and G. C. Wonn. Thermal Conductivity and Electrical Resistivity of UC," Carbides in Nuclear Energy V-1, edited by I. E. Russeiz. Collier-Macmizlan,Limited, London, 1964. pp.365-372

12. M. J. Wheeler. "Thermal Conductivity of Uranium Monocarbide," Carbides in Nuclear Energy, Vol. 1, edited by L. R. Russeli. Collier-Macmillan, Limited, London, 1964. pp. 407-411. 
13. S. C. Carniglia. "Single Crystal and Dense Polycrystal Uranium Carbide: Thermal, Mechanical and Chemical Properties," Carbides in Nuclear Energy, Vol. 1, edited by L. R. Russeli. Collier-Macmillan,Limited, London, 1964. pp. 407-411, NAA-SR-MEMO-9015, November 1963.

14. J. T. Sobon, A. D. Milzer, and M. A. DeCrescente. The Thermal Conductivity of Uranium Monocarbide, CNLM-5 $\overline{621}$. Pratt and Whitney Aircraft Division, United Aircraft Corp., Middletown, Conn., 1964.

15. M. A. DeCrescente and A. D. Mizler. "High Temperature Properties of Uranium Carbide," Carbides in Nuclear Energy, Vol. I, edited by L. R. Russelz. Collier-Macmilzan, Limited, London, 1964. pp. 342-357.

16. L. J. Wittenberg and G. R. Grove. Reactor Fuels and Materials Development Plutonium Research: July-September 1964, MLM-1220. Mound Laboratory, Miamisburg, ohio, 1964.

17. P. Costa and $R$. LalZement. "Etude de Za Structure EZectronique des carbures de Thorium d'Uranium et de Plutonium," J. Phys. Chem. Solids, vol. 25, pp. 559-564. 1964 .

18. B. A. Hayes and M. A. DeCrescente. Thermal Conductivity and Electrical Resistivity of Uranium Monocarbide, PWAC480. Pratt and Whitney Aircraft Division, United Aircraft Corp., Hartford, Conn., 1965.

19. K. M. Tayzor, J. C. Andersen, A. Strasser, D. Stahl and R. L. Forbes. "Monoxide - Type Compounds of Uranium and Plutonium: I, Oxycarbides," J.Am. Cer. Soc., vol. 50, no. 6, pp. 323-325. 1967 .

20. J. B. Moser and O. L. Kruger. "Thermal Conductivity and Heat Capacity of the Monocarbide, Monophosphide, and Monosulfide of Uranium," J. Appl. Phys., vol. 38, no. 8, pp. 3215-3222. 1967 .

21. I. H. Warren and J. Lacis. Unpublished Data. University of British Columbia, Vancouver Canada, october 1967. (Personal Communication)

22. J.A. Leary. Plutonium Fuels, LADC-6712. Los Alamos Scientific Laboratory, Los Alamos, New Mexico, october 20, 1964.

23. 2. Mihaizovic. "Conductivite Thermique du Monocarbure d'Uranium," (Unpublished data quoted in Reference 9). 


\section{APPENDIX B}

\section{CALIBRATION OF THERMAL DIFFUSIVITY APPARATUS}

The accuracy of the thermal diffusivity values and of the pulse technique was evaluated by measuring the thermal diffusivity of Armco iron. Armco iron is considered by many investigators to be a thermal conductivity standard. Recent reviews of the published thermal conductivity data for Armco iron between room temperature and $760^{\circ} \mathrm{C}$ indicate a data spread of about $4 \%$. (1)

The thermal diffusivity was determined for Armco iron samples of two thicknesses $(0.140$ and $0.071 \mathrm{~cm})$. Measurements were made during three temperature cycles from 25 to less than $800{ }^{\circ} \mathrm{C}$. The results are illustrated in Figures $\mathrm{B}-1$ and $\mathrm{B}-2$, and tabulated in Table A-1.

Two investigators $(2,3)$ have measured the thermal diffusivity of Armco iron. These data are the basis for the accuracy evaluations of the pulse technique. The average values of the thermal diffusivity using data of Cody et al., (2) Shanks et al., (3) and this study were used to determine the percent deviation from room temperature to $765^{\circ} \mathrm{C}$ (Figure B-3). With the exception of two data points, the data fall within $\pm 3.5 \%$ of the average. The data of Cody et al. exhibit a deviation of $\pm 3.0 \%$ with all values falling below the average. The data of Shanks et al., show a deviation of $\pm 2.0 \%$ with all values above the average. 


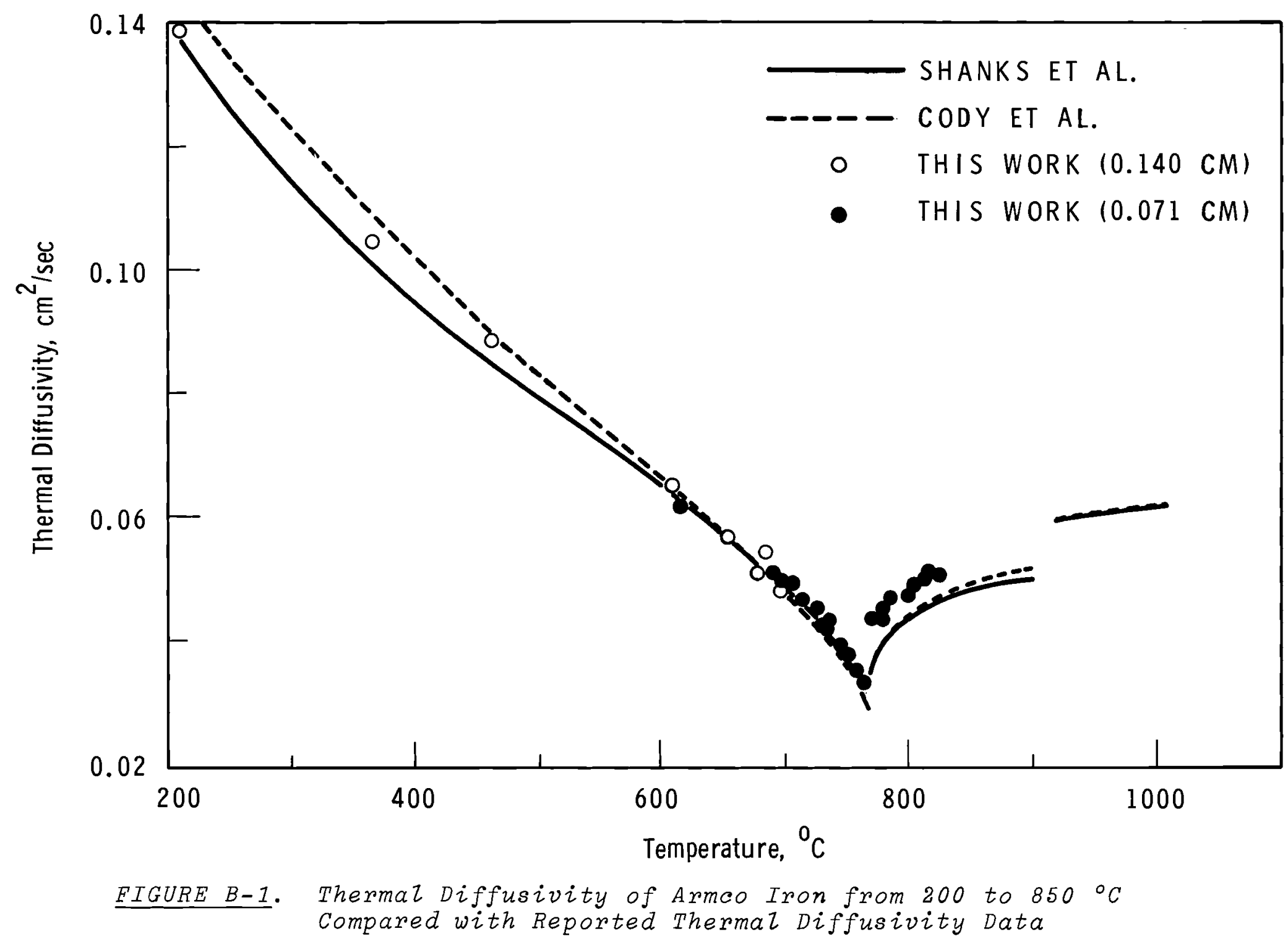

$\infty$
1
$N$ 


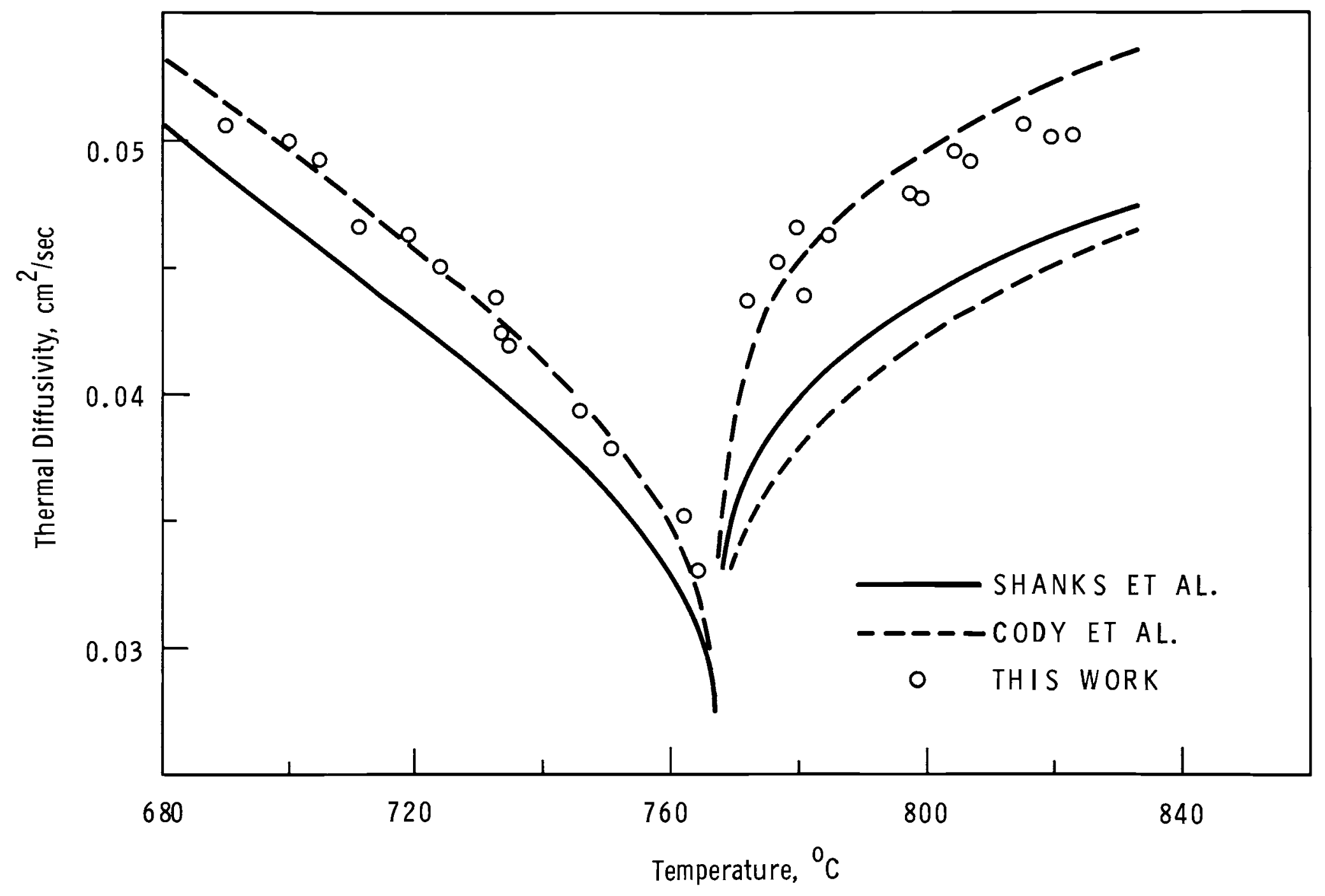




\section{TABLE B-1. Thermal Diffusivity of Armeo Iron} Temperature, Thermal Diffusivity,
${ }^{\circ} \mathrm{C}$

\begin{tabular}{llll}
\hline & \multicolumn{2}{c}{$0.071 \mathrm{~cm}$ Thick } & \\
615 & 0.0620 & 772 & 0.0436 \\
690 & 0.0497 & 780 & 0.0451 \\
697 & 0.0480 & 781 & 0.0463 \\
705 & 0.0483 & 785 & 0.0461 \\
714 & 0.0455 & 797 & 0.0478 \\
721 & 0.0452 & 799 & 0.0476 \\
724 & 0.0444 & 804 & 0.0494 \\
734 & 0.0415 & 815 & 0.0490 \\
746 & 0.0386 & 819 & 0.0505 \\
763 & 0.0346 & 823 & 0.0500 \\
765 & 0.0323 & & 0.0501 \\
751 & 0.0370 & & \\
735 & 0.0410 & & \\
733 & 0.0428 & 655 & \\
& 0.01386 & $\mathrm{~cm}$ & \\
210 & 0.01047 & 680 & 0.0575 \\
366 & 0.0890 & 700 & 0.0559 \\
460 & 0.0655 & &
\end{tabular}




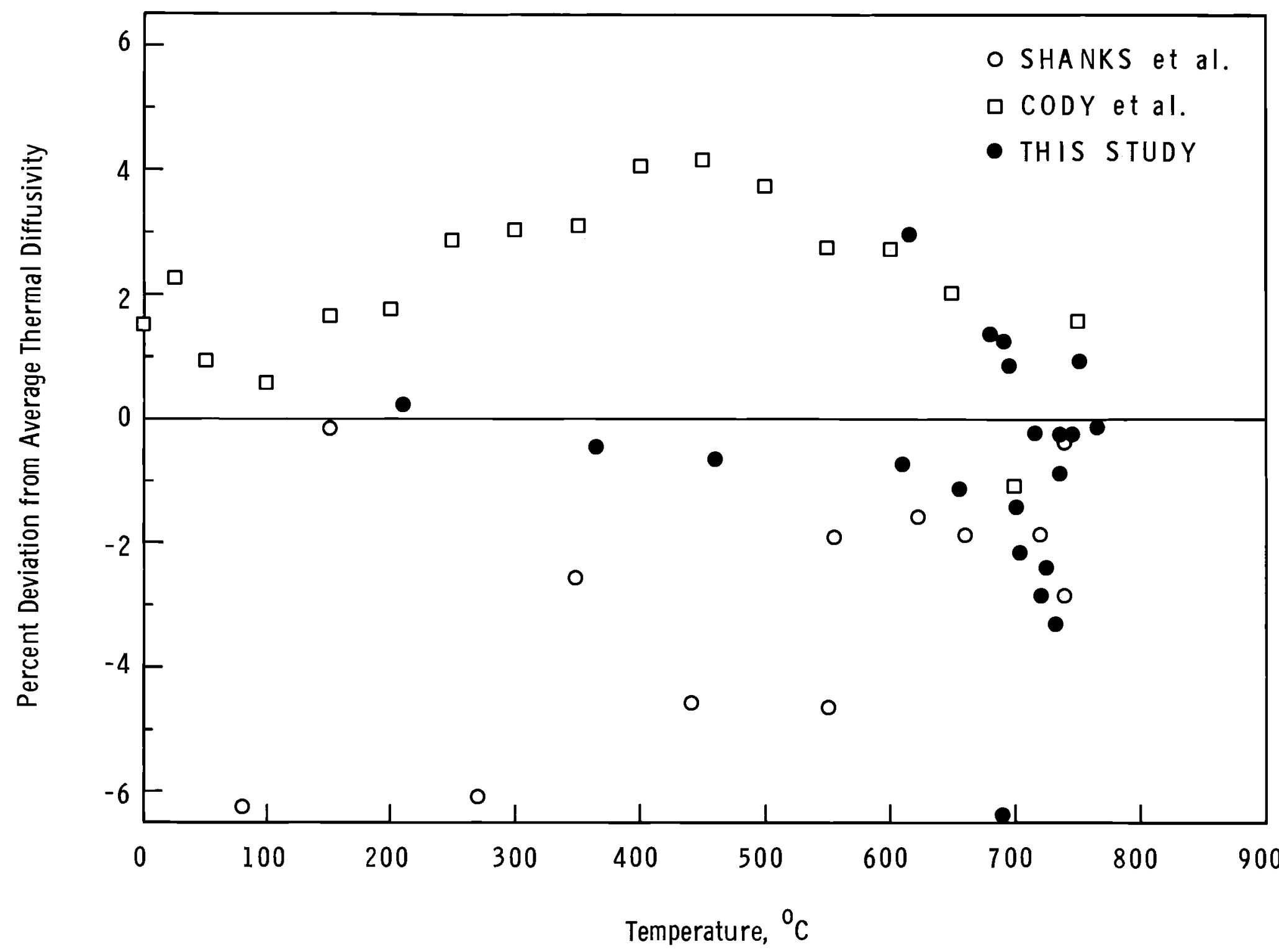

FIGURE B-3. Percent Deviation of Reported Thermal Diffusivity Data 


\section{REFERENCES}

1. T. G. Godfrey, W. Fulkerson, T. G. Kollie, J. P. Moore, and D. L. MCEZroy. Thermal Conductivity of Uranium Dioxide and Armco Iron by an Improved Radial Heat Flow Technique, ORNL-3556. Oak Ridge National Laboratory, Oak Ridge, Tennessee, June 1964.

2. G. D. Cody, B. Abeles, and D. S. Beers. "Thermal Diffusivity of Armeo Iron," Trans. Met. Soc. AIME, vol. 221, no. 2, p. 25. 1961 .

3. H. R. Shanks, A. H. Klein, and G. C. Danielson. "Thermal Properties of Armco Iron," J. Appl. Phys., vol. 38, no. 7, pp. $2885-2892$. 1967. 


\section{APPENDIX C}

THERMAL DIFFUSIVITY/CONDUCTIVITY OF URANIUM OXYCARBIDE

TABLE C-1. Thermal Diffusivity/Conductivity Data of Uranium oxycarbide

\begin{tabular}{|c|c|c|}
\hline \multicolumn{2}{|c|}{ SPECIMEN UCON - 283} & \multirow{2}{*}{$\begin{array}{c}\frac{0.495^{\mathrm{C}} 0.485^{\circ} 0.02}{\text { Therma1 Conductivity, }} \\
\text { W/ } \mathrm{cm}^{\circ}{ }^{\circ} \mathrm{C}\end{array}$} \\
\hline $\begin{array}{c}\text { Temperature, } \\
{ }^{\circ} \mathrm{C}\end{array}$ & $\begin{array}{c}\text { Therma1 Diffusivity, } \\
\mathrm{cm}^{2} / \mathrm{sec}\end{array}$ & \\
\hline 101 & 0.0723 & 0.194 \\
\hline 408 & 0.0639 & 0.191 \\
\hline 512 & 0.0614 & 0.187 \\
\hline 612 & 0.0596 & 0.184 \\
\hline 672 & 0.0597 & 0.185 \\
\hline 800 & 0.0569 & 0.179 \\
\hline 808 & 0.0568 & 0.180 \\
\hline 660 & 0.0598 & 0.185 \\
\hline 395 & 0.0625 & 0.185 \\
\hline 997 & 0.0559 & 0.181 \\
\hline 1002 & 0.0546 & 0.177 \\
\hline 1206 & 0.0564 & 0.181 \\
\hline 1297 & 0.051 .2 & 0.178 \\
\hline 1393 & 0.0521 & 0.182 \\
\hline 1405 & 0.0546 & 0.191 \\
\hline 1500 & 0.0530 & 0.189 \\
\hline 1400 & 0.0544 & 0.190 \\
\hline 1302 & 0.0547 & 0.187 \\
\hline 1103 & 0.0530 & 0.175 \\
\hline 1002 & 0.0558 & 0.181 \\
\hline
\end{tabular}


Temperature, Thermal Diffusivity, Thermal Conductivity, ${ }^{\circ} \mathrm{C}$ $\mathrm{cm}^{2} / \mathrm{sec}$ $\mathrm{W} / \mathrm{cm}-{ }^{\circ} \mathrm{C}$

$\begin{array}{llr}0.0464 & 0.128 & 185 \\ 0.0458 & 0.132 & 334 \\ 0.0457 & 0.134 & 400 \\ 0.0452 & 0.135 & 517 \\ 0.0443 & 0.134 & 623 \\ 0.0447 & 0.137 & 711 \\ 0.0438 & 0.136 & 800 \\ 0.0455 & 0.144 & 918 \\ 0.0449 & 0.143 & 998 \\ 0.0441 & 0.139 & 894 \\ 0.0451 & 0.140 & 810 \\ 0.0442 & 0.135 & 674 \\ 0.0442 & 0.133 & 564 \\ 0.0444 & 0.130 & 424 \\ 0.0453 & 0.128 & 285 \\ 0.0447 & 0.124 & 228 \\ 0.0453 & 0.130 & 270 \\ 0.0462 & 0.148 & 996 \\ 0.0459 & 0.149 & 1102 \\ 0.0468 & 0.155 & 1196 \\ 0.0465 & 0.157 & 1301 \\ 0.0455 & 0.156 & 1402 \\ 0.0475 & 0.163 & 1401 \\ 0.0446 & 0.147 & 1202 \\ 0.0453 & 0.147 & 1109 \\ 0.0452 & 0.144 & 1000\end{array}$




\begin{tabular}{|c|c|c|}
\hline \multicolumn{2}{|c|}{ SPECIMEN UCON- 289} & $0.495^{\mathrm{C}} 0.335^{\mathrm{O}} 0.017$ \\
\hline $\begin{array}{c}\text { Temperature, } \\
{ }^{\circ} \mathrm{C} \\
\end{array}$ & $\begin{array}{l}\text { Thermal Diffusivity, } \\
\mathrm{cm}^{2} / \mathrm{sec}^{-}\end{array}$ & $\begin{array}{c}\text { Thermal Conductivity, } \\
\mathrm{W} / \mathrm{cm}^{\circ}{ }^{\circ} \mathrm{C} \\
\end{array}$ \\
\hline 218 & 0.0429 & 0.119 \\
\hline 360 & 0.0440 & 0.126 \\
\hline 445 & 0.0448 & 0.131 \\
\hline 560 & 0.0439 & 0.130 \\
\hline 660 & 0.0447 & 0.134 \\
\hline 785 & 0.0445 & 0.136 \\
\hline 890 & 0.0454 & 0.140 \\
\hline 998 & 0.0455 & 0.143 \\
\hline 896 & 0.0454 & 0.140 \\
\hline 796 & 0.0437 & 0.133 \\
\hline 706 & 0.0439 & 0.132 \\
\hline 604 & 0.0440 & 0.131 \\
\hline 503 & 0.0439 & 0.128 \\
\hline 408 & 0.0429 & 0.123 \\
\hline 794 & 0.0449 & 0.137 \\
\hline 885 & 0.0466 & 0.144 \\
\hline 1000 & 0.0473 & 0.149 \\
\hline 980 & 0.0463 & 0.145 \\
\hline 1071 & 0.0463 & 0.147 \\
\hline 1194 & 0.0465 & 0.151 \\
\hline 1287 & 0.0481 & 0.159 \\
\hline 1407 & 0.0462 & 0.156 \\
\hline 1400 & 0.0489 & 0.165 \\
\hline 1297 & 0.0461 & 0.153 \\
\hline 1202 & 0.0456 & 0.148 \\
\hline 1001 & 0.0466 & 0.147 \\
\hline
\end{tabular}


SPECIMEN UCON -365

$$
\mathrm{U}_{0.48} \mathrm{C}_{0.49^{\mathrm{O}} 0.03}
$$

Temperature, Thermal Diffusivity, Thermal Conductivity,

${ }^{\circ} \mathrm{C}$

133

333

530

542

671

790

844

891

1101

1200

1302

1401

1501

1298

1204

419

1225

1495

1373

746

421

195 $\mathrm{cm}^{2} / \mathrm{sec}$

0.0563

0.0535

0.0521

0.0528

0.0507

0.0514

0.0507

0.0506

0.0498

0.0498

0.0507

0.0506

0.0493

0.0490

0.0493

0.0542

0.0512

0.0505

0.0490

0.0525

0.0546

0.0563
$\mathrm{W} / \mathrm{cm}-{ }^{\circ} \mathrm{C}$

0.162

0.163

0.164

0.167

0.162

0.167

0.166

0.167

0.169

0.173

0.179

0.182

0.181

0.173

0.171

0.166

0.179

0.186

0.175

0.169

0.167

0.162 


\section{APPENDIX D}

ELECTRICAL RESISTIVITY OF URANIUM OXYCARBIDE

TABLE D-1. Electrical Resistivity Data of Uranium Oxycarbide

\begin{tabular}{|c|c|c|c|}
\hline $\begin{array}{c}\text { Temperature, } \\
{ }^{\circ} \mathrm{C} \\
\end{array}$ & $\begin{array}{l}\text { Electrical } \\
\text { Resistivity, } \\
\mu \text { ohm-cm } \\
\end{array}$ & $\begin{array}{c}\text { Temperature, } \\
{ }^{\circ} \mathrm{C}\end{array}$ & $\begin{array}{c}\text { Electrical } \\
\text { Resistivity, } \\
\mu \text { ohm-cm } \\
\end{array}$ \\
\hline 21 & 89 & 763 & 165 \\
\hline 21 & 92 & 1008 & 187 \\
\hline 21 & 103 & 1011 & 188 \\
\hline 21 & 88 & 1111 & 197 \\
\hline 21 & 86 & 1114 & 198 \\
\hline 28 & 89 & 1201 & 206 \\
\hline 39 & 88 & 1210 & 208 \\
\hline 49 & 93 & 1303 & 214 \\
\hline 101 & 97 & 1301 & 217 \\
\hline 118 & 101 & 1370 & 221 \\
\hline 175 & 107 & 1376 & 222 \\
\hline 201 & 111 & 1419 & 229 \\
\hline 263 & 116 & 1449 & 230 \\
\hline 334 & 125 & 1490 & 236 \\
\hline 354 & 124 & 1505 & 237 \\
\hline 433 & 133 & 1358 & 222 \\
\hline 464 & 134 & 1181 & 204 \\
\hline 475 & 135 & 1032 & 189 \\
\hline 469 & 135 & 864 & 172 \\
\hline 574 & 145 & 638 & 148 \\
\hline 567 & 146 & 482 & 130 \\
\hline 665 & 156 & 320 & 114 \\
\hline 664 & 154 & 240 & 105 \\
\hline \multirow[t]{3}{*}{747} & 163 & 146 & 91 \\
\hline & & 12 & 73 \\
\hline & & 12 & 80 \\
\hline
\end{tabular}




\begin{tabular}{|c|c|c|c|}
\hline $\begin{array}{c}\text { Temperature, } \\
{ }^{\circ} \mathrm{C}\end{array}$ & $\begin{array}{l}\text { Electrical } \\
\text { Resistivity, } \\
\quad \mu \text { ohm-cm } \\
\end{array}$ & $\begin{array}{c}\text { Temperature, } \\
{ }^{\circ} \mathrm{C}\end{array}$ & $\begin{array}{l}\text { Electrical } \\
\text { Resistivity, } \\
\mu \text { ohm-cm } \\
\end{array}$ \\
\hline 21 & 114 & 1264 & 284 \\
\hline 21 & 110 & 1347 & 291 \\
\hline 21 & 106 & 1341 & 292 \\
\hline 21 & 105 & 1420 & 300 \\
\hline 21 & 104 & 1425 & 300 \\
\hline 24 & 106 & 1491 & 305 \\
\hline 35 & 107 & 1494 & 305 \\
\hline 51 & 110 & 1425 & 298 \\
\hline 53 & 110 & 1418 & 299 \\
\hline 87 & 121 & 1260 & 281 \\
\hline 93 & 125 & 1242 & 282 \\
\hline 197 & 142 & 1025 & 248 \\
\hline 209 & 141 & 942 & 241 \\
\hline 334 & 161 & 765 & 223 \\
\hline 339 & 161 & 828 & 229 \\
\hline 502 & 185 & 688 & 207 \\
\hline 507 & 187 & 651 & 203 \\
\hline 630 & 204 & 485 & 178 \\
\hline 640 & 204 & 454 & 176 \\
\hline 791 & 231 & 320 & 161 \\
\hline 823 & 229 & 205 & 143 \\
\hline 1023 & 255 & 166 & 140 \\
\hline 1033 & 256 & 77 & 127 \\
\hline 1126 & 269 & 42 & 102 \\
\hline 1133 & 269 & 23 & 101 \\
\hline 1205 & 277 & 23 & 107 \\
\hline 1201 & 277 & & \\
\hline 1264 & 284 & & \\
\hline
\end{tabular}




\title{
DISTRIBUTION
}

No. of

Copies

OFFS ITE

AEC Chicago Patent Group

G. H. Lee

AEC Division of Reactor Development

and Technology

G. W. Cunningham

J. M. Simmons

AEC Division of Research

D. K. Stevens

\author{
260 AEC Division of Technical Information Extension \\ 2 Air Force Materials Laboratory \\ G. L. Denmon \\ M. L. Minges \\ $1 \quad$ Allgemein Eleklugitats Gesel1schaft \\ Frankfurt AEG Hochhaus \\ Federal Republic of Germany \\ J . Höche 1 \\ Argonne National Laboratory \\ J. H. Handwerk \\ R. J. Thorn \\ Atomic Energy of Canada, Limited \\ Fuels and Materials Division \\ Fuel Materials Branch \\ Chalk River, Ontario, CANADA \\ J. R. MacEwan \\ M. F. Notley \\ J.A. L. Robertson \\ Atomic Energy Research Establishment \\ United Kingdom Atomic Energy Authority \\ Harwe11, Didcot, Berks, ENGLAND \\ L. E. Russe11 \\ J. Williams
}


No. of

Copies

3

1

1

2

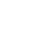

3

1

1

1
Battelle Memorial Institute (AEC)

H. Deem

O. L. Kruger

W. Pardue

Bettis Atomic Power Laboratory (AEC)

J. Belle

Brookhaven National Laboratory (AEC)

A. Auskern

Centre d'Etudes Nucleaires

Fontenay-aux-Roses, Seine, FRANCE

R. La11ement

J. C. Van Craeynest

Centre d'Etude Nucleaires de Grenoble Grenoble, FRANCE

J. P. Stora

Comitato Nazionale Energia Nucleare

C. S. N. Casaccia Laboratorio

Rome, ITALY

S. Moretti

Genera1 Electric Company, Cincinnati (AEC)

A. T. Feith

H. C. Brassfield

R. E. Fryxe11

General Electric Company, Pleasanton (AEC)

E. A. Aitkens

Los Alamos Scientific Laboratory (AEC)

J. A. Leary

National Bureau of Standards

D. R. Flynn 
No. of

Copies

1

4

3

1

1

1

1

National Research Council

Division of Applied Physics

Ottawa, Ontario, CANADA

M. J. Laubitz

Oak Ridge National Laboratory (AEC)

W. Fulkerson

D. L. McElroy

J. P. Moore

J. L. Scott

Purdue University

Thermophysical Properties Research Center West Lafayette, Indiana

R. L. Powe 11

R. E. Taylor

Y. S. Touloukian

Tokyo Shibaura Electric Co., Ltd.

Center Research Laboratory

Komukoi, Kawasaki, JAPAN

T. Nishijima

Iransuranium Institute (Euratom)

Kar1sstrasse 42-44

Karlsruhe, GERMANY

H. M. Mattys

H. C. Schmidt

University of British Columbia

Vancouver, BRITISH COLUMBIA

I. H. Warren

University of Washington

Ceramics Department

J. E. Mueller

United States Bureau of Mines

Albany Research Center

Albany, Oregon

J . L. Henry 
No. of

Copies

ONS ITE-HAN FORD

1

AEC Chicago Patent Group

R. K. Sharp (Richland)

2

AEC RDT Site Representative

P. G. Holsted

1

AEC Richland Operations Office

C. L. Robinson

Batte1le Memorial Institute

1 Dona1d W. Douglas Laboratory

Richland, Washington

R. D. Allen

$\underline{\text { Batte 11e-Northwest }}$

W. J. Bailey

J. A. Basmajian

J. L. Bates (30)

D. E. Baker

T. K. Bierlein

L. D. Blackburn

T. D. Chikalla

J. A. Christensen

G. M. Dalen

J. L. Daniel

D. R. de Halas

K. Drumheller

E. A. Evans

P. L. Farnsworth

M. D. Freshley

R. L. Gibby

J. E. Hansen
P. E. Hart

B. R. Hayward

C. A. Hinman

G. R. Horn

C. E. McNeilly

K. R. Merckx

R. P. Nelson

R. E. Nightingale

D. R. Packard

J. J. Rasmussen

W. E. Roake

O. D. Slagle

G. L. Tingey

C. E. Vogel

E. T. Weber

H. H. Yoshikawa

Technical Information

$$
\text { Files (5) }
$$

Technical Publications 